RESEARCH PAPER RP1207

\author{
Part of Journal of Research of the National Bureau of Standards, Volume 22, \\ May 1939
}

\title{
DISTRIBUTION OF OZONE IN THE STRATOSPHERE
}

\author{
By W. W. Coblentz and R. Stair
}

\section{ABSTRACT}

Measurements of the spectral quality and total intensity of ultraviolet solar radiation at a fixed ground station and at various elevations above the earth's surface are described.

For making measurements at a fixed ground station at a high elevation (Flagstaff, Ariz., elevation $2.2 \mathrm{~km}$ ), a portable ultraviolet-intensity meter, consisting of a balanced amplifier, $T i$-photoelectric cell, and microammeter was used, see RP647.

For measuring solar radiation in the stratosphere, an ultraviolet-intensity meter (consisting of a $\boldsymbol{C d}$-photoelectric cell and filter radiometer, connected with a balanced amplifier, relaxation oscillator, and radio transmitter) and a radio-operated barometer were transported aloft by means of unmanned balloons. The audiofrequency modulated radio wave, giving the intensity of the ultraviolet solar radiation and the altitude of the apparatus, was received and graphically recorded at a fixed ground station, see RP1075.

In the measurements at Flagstaff, Ariz., a close parallelism was observed in the variation in filter transmission with variation in barometric pressure. This is in agreement with the well-known variation in the amount of atmospheric ozone that accompanies changes in air pressure. No such systematic variation in filter transmission with variation in pressure of atmospheric aqueous vapor was observed.

A notable example is described in which the wave of low barometric pressure preceded, by 5 to 6 hours, an appreciable increase in atmospheric ozone; apparently indicating which was cause and which was effect, and suggesting a method of studying air circulation in the stratosphere.

In four balloon ascensions made in June 1938, the photoelectric ultravioletintensity meter and auxiliary radio-transmitting apparatus attained heights of 83,000 to $88,000 \mathrm{ft}$ (25 to $27 \mathrm{~km}$ ), penetrating about 65 percent of the ozone, the most of which was localized in a layer extending from an elevation of 18 to $27 \mathrm{~km}$, with a wide maximum of concentration at a height of about $25 \mathrm{~km}$. At the highest elevation attained by the instruments, the intensity of the ultraviolet of short wave lengths was about 10 times that of direct sunlight at sea level.

\section{CONTENTS}

I. Introduction

1. Relation between meteorological conditions and the amount of ozone in the atmosphere

II. Ultraviolet solar measurements at Flagstaff, Arizona.

1. Measurements of sky radiation $\ldots \ldots$

2. Diurnal variation in ultraviolet solar radiation ................ 580

3. Correlation of atmospheric transmission of ultraviolet solar radiation with barometric pressure

4. Variation in atmospheric transmission of ultraviolet solar radiation with turbulence in the ozone layer.............. 588

5. Air-mass analysis of October 5, 1938_............... 590

III. Exploration of the vertical distribution of ozone in the stratosphere.-- 590

1. Description of the radio-operated ultraviolet-intensity meter . _ 591

2. Description of improvements in the radio circuit of the photoelectric ultraviolet-intensity meter 
III. Exploration of the vertical distribution of ozone in the stratosphereContinued.

3. Description of a balloon-flight record . _ _ _ _ _ _ 594

(a) Notes on the six flights _.

4. Evaluation of the ultraviolet-intensity measurements

(a) Variation in intensity of ultraviolet solar radiation with

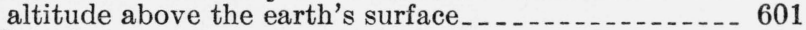

(b) Calculation of the amount of ozone traversed....... 601

(c) Vertical distribution of ozone in the atmosphere....... 604

IV. References and notes.

\section{INTRODUCTION}

An exploration of the vertical distribution of ozone in the stratosphere by measuring the intensity of ultraviolet solar radiation with a photoelectric cell and filter radiometer [1], ${ }^{1}$ at different elevations above the earth's surface, was first considered in 1934 in connection with the flights of manned balloons [2].

The chief problem then was (and still is) the lack of a satisfactory photoelectric cell for measuring the ultraviolet intensity. Moreover, since nearly all the auxiliary equipment for such an undertaking remained undeveloped, but little progress was made in the design of suitable apparatus prior to the middle of the summer of 1935-too late to take part in the flight of the Explorer II which occurred on November 11, 1935 [2].

It was therefore decided to redesign the apparatus to make it transportable in small, inexpensive, unmanned balloons. This required a great reduction in the weight of all the essential parts that must be transported. Fortunately, through rapid developments then in progress in radio transmission as applied to meteorographs [3, 4], it became possible to leave a large part of the measuring and recording apparatus at a fixed ground station, and the weight of the apparatus to be transported aloft could be reduced to a few kilograms.

The part of the apparatus that must be sent aloft is relatively inexpensive. Hence, even if it is lost or broken in the descent, numerous flights are possible, and more data are obtainable at a less cost than in a single flight in a manned balloon.

The proposed method, and the first progress made in the development of a radiometric ultraviolet-intensity meter, consisting of a photoelectric cell and filter radiometer, and auxiliary radio-transmitting apparatus, to be transported aloft by sounding balloons, was described early in 1936 [4].

In the summer of 1937 quantitative measurements of ultraviolet solar intensities were obtained to a height of $64,000 \mathrm{ft}(19 \mathrm{~km})$ above sea level $[5,6]$. The failure to obtain measurements at higher elevations was due to lack of power in that part of the radio-transmitting apparatus controlled by the photoelectric cell. The radio barograph indicated that the apparatus attained a height of $78,000 \mathrm{ft}(24 \mathrm{~km})$.

In the meantime, through improvements made in the radio-transmitting apparatus [7], during the summer of 1938 it was possible to secure quantitative measurements of ultraviolet solar intensities to the highest elevations $(27 \mathrm{~km}$ ) attained by the transporting balloons.

The object of the present communication is to describe the results of the ultraviolet solar-intensity measurements, obtained, in June 1938, by means of a radio-operated photoelectric cell and filter radiometer

1 Figures in brackets indicate the literature references and notes at the end of this paper. 
transported aloft by means of sounding balloons; also supplementary measurements made in September and October 1938, at the Lowell Observatory, Flagstaff, Ariz. (elevation 7,300 ft) for the purpose of determining the effect of humidity and of sky radiation upon ultraviolet intensities, which information is of interest in connection with the stratosphere measurements.

The sky radiation was measured with a $C d$-photoelectric cell previously used in one of the stratosphere flights (flight 1 ). The effect of humidity and of clouds upon the spectral quality of the directly incident ultraviolet solar radiation was measured with one of the Tiphotoelectric cells and the glass filters used in similar measurements made in 1934 [8]. In the present measurements a higher precision was obtained than 4 years ago.

\section{RELATION BETWEEN METEOROLOGICAL CONDITIONS AND THE AMOUNT OF OZONE IN THE ATMOSPHERE}

Based upon researches of various observers, extending over the past 15 or more years, it appears to be definitely established that, in vertical distribution, ozone exists throughout the whole atmosphere, to a height of perhaps $40 \mathrm{~km}$; with the most of it concentrated in a layer having a maximum density at a height of 20 to $25 \mathrm{~km}$ above sea level. It is the only atmospheric gas that has such a stratification.

In high latitudes (Tromsö, $69^{\circ} 40^{\prime}$ ) the ozone appears to be concentrated in a layer centered at a height of about $21 \mathrm{~km}$ above sea level, whereas at Arosa, Switzerland $\left(46^{\circ} 45^{\prime} \mathrm{N}\right)$ it is more uniformly distributed through the lower $30 \mathrm{~km}$ [17], as observed in the present investigation.

In geographic distribution, the total amount of ozone increases with latitude, being about $2 \mathrm{~mm}$ in thickness (ntp) at the equator and 3.5 $\mathrm{mm}$ or more in Northern latitudes (Spitzbergen, $78^{\circ} 55^{\prime} \mathrm{N}$ ).

There is a seasonal variation in the ozone content of the atmosphere, which is a maximum in the local spring (March, in the Northern Hemisphere) and a minimum in the local autumn [10, 14]. The seasonal variation is small at the equator and different in different latitudes. The difference between the average ozone content at the poles and at the equator is about four times as great in the spring as in the autumn [12].

The maximum ozone values are associated with air currents which (at least in the troposphere), in the Northern Hemisphere, have recently come from the Arctic. They are particularly high in the spring, after the long polar night. Similarly, the smallest ozone values are associated with tropical air currents in the troposphere $[11,14]$. Nothing appears to be known regarding the circulation of air currents in the ozone layer. According to Dobson [11], it is necessary to assume their direction to be opposite to those in the troposphere in order to support the hypothesis that ozone is formed chiefly by sunshine.

Marked daily variations in the amount of atmospheric ozone occur with varying meteorological conditions; relatively large amounts being generally observed with low barometric pressures (cyclonic regions) and relatively much smaller amounts with high barometric pressures (anticyclonic regions) [10, 12, 13]. 
Although it is presumed [9] that the amount of ozone in the atmosphere is greater in the morning than in the evening, as is probably to be expected, observers differ in their findings-Goetz and Dobson [19] reporting no diurnal variation of ozone, whereas Coblentz and Stair [8] recorded occasional variations (less ozone in the afternoon than the forenoon). But whether this variation was due to decomposition of ozone, or accompanies a change in barometric pressure (as herein reported) was not determined. ${ }^{2}$

In addition to this diurnal variation in ozone, Coblentz and Stair [8] observed also a temporary departure from (above or below) the seasonal average. Whether these variations in ozone content (observed at Flagstaff, Ariz., elevation 2,210 m) were caused by cyclonic and anticyclonic conditions was not determined. ${ }^{3}$

Recently such variations in the amount of atmospheric ozone were observed by Kiepenheuer [15] while making spectral ultraviolet measurements on the Jungfraujoch (elevation $3,460 \mathrm{~m}$ ). He ascribes these variations to passing "Ozone clouds" and "Ozone holes," which caused great fluctuations in intensity of ultraviolet spectral radiation, particularly at the wave length 2880 A. From his description it appears that his so-called "Ozone holes" were caused by the circulation of masses of air which contained a low concentration of ozone, thereby increasing, for a short time, the transparency of the air to ultraviolet radiation, as observed in the Arizona measurements of 1934 [8].

In a recent paper, Meetham [16] reported the results of a study of the connection between the amount of ozone in the upper atmosphere, at any place, and the type of pressure disturbance at sea level. For this purpose he made use of the statistical data available, showing that over a low-pressure area (a) the tropopause is abnormally low, (b) the actual shortage of air, which is responsible for the low pressure, occurs chiefly in the stratosphere, and (c) the ozone density is unusually large in the lower stratosphere.

To account for the known facts, he found it necessary to assume an appreciable amount of vertical circulation in the stratosphere and he added "Distasteful as this assumption is, it provides one more reason why turbulence in the stratosphere should be further investigated."

In the ensuing discussion of this paper, Dobson emphasizes that the difficulty in such an analysis lies in separating cause from effect, and he concludes with the remark that it is "still a matter of doubt whether the amount of ozone is affected by the weather conditions, or vice versa." As will be shown presently, with the arrival of the wave of low barometric pressure (on October 5 at Flagstaff, Ariz.) some 5 to 6 hours in advance of the high concentration of ozone, it would appear that, at least in this particular instance, weather conditions were the controlling factor (the "cause") in changing the concentration of ozone. Whether this was the result of an influx of polar

${ }_{2}^{2}$ The diurnal high air pressure at Flagstaff, Ariz., occurs at about 10 a. m. (and 10 p. m.). Hence, if it should be found to be generally true that the variation in the ozone content of the atmosphere lags some hours behind the variation in barometric pressure, then the relatively lower ozone content observed at $1: 30$ to $3: 30$ p. m. would be associated with the diurnal barometric high pressure that occurred at 10:00 to 10:30 a. m. Evidently a study should be made of this phenomenon, using ultraviolet solar radiation; also infrared solar radiation, especially the spectral range comprising the large absorption band of ozone at $9.6 \mu$ which falls within the band of relatively high transparency to atmospheric water vapor and relatively high intensity of solar radiation [18, 27].

Since writing this paper, C. O. Lampland, of the Lowell Observatory, has sent us photographic copies of barograph records which show that on July 24,27 , and 30,1934 , when the observed filter transmissions were lower (ozone lower) than the average, the air pressure was 2.5 to $3 \mathrm{~mm}$ higher than the average; in good agreement with the measurements described in Section II (see nig. 4) of the present paper. However, since the precision attained in these earlier measurements was not comparable with this year's measurements, less weight is to be attached to the earlier observations. 
air containing a higher concentration of ozone, or merely fresh oxygen that was then ozonized (as some have speculated), adds another complication to the solution of the problem.

In view of all the work that has been done during the past 15 or more years, it is surprising to find practically no information on the time of arrival of the wave of high concentration of ozone relative to the time of arrival of the wave of low barometric pressure. This may be owing to the method of observation, which consisted in measuring (photographing) the solar ultraviolet spectrum, morning, noon, and evening. Hence, there was no continuous record. Kidson [12], working in New Zealand, in attempting a correlation of ozone with barometric pressure, finds the best agreement by comparing the amount of ozone on a given day with the barometric pressure of the preceding day - a lag of 20 hours or more, in perception of the change in the amount of ozone after a change in barometric pressure.

In concluding this part of the discussion, it is to be noted that all the researches show that the low barometer does not appear to be the cause, but to accompany the cause, of the influx of ozone. For example, the measurements made by Barbier, Chalonge, and Vassy [20] during the polar winter of 1935 at Abisko, Sweden (Lat. $68^{\circ} 20^{\prime} \mathrm{N}$ ), show that the thickness of the ozone layer changed from $1.87 \mathrm{~mm}$ on January 25 to $4.04 \mathrm{~mm}$ on January 26, coincident with a great influx of Arctic air that extended to Spain. Yet, according to the weather map (data supplied by E. W. Woolard of the Weather Bureau), the drop in barometric pressure was relatively small-about $2.5 \mathrm{~mm}$ (0.1 in.).

\section{ULTRAVIOLET SOLAR MEASUREMENTS AT FLAGSTAFF, ARIZONA}

Supplementing the ultraviolet solar-radiation measurements made with sounding balloons, described in the following section of this paper, it was of interest to obtain similar measurements of spectral quality and total intensity through a cloudless sky at a terrestrial station having a high elevation.

Through the courtesy of V. M. Slipher, Director of the Lowell Observatory, Flagstaff, Ariz., elevation 7,300 ft. $(2,210 \mathrm{~m})$, it was possible for one of us (W.W.C.) to make ultraviolet solar-intensity measurements, thus extending the investigation begun in 1934 [8].

Information on the variation of the amount of ozone in the atmosphere is obtained from measurements of the spectral quality and total intensity of ultraviolet solar radiation of wave lengths shorter than about $3200 \mathrm{~A}$, which are greatly absorbed by this gas. The measurements are made by means of a portable ultraviolet-intensity meter [1] consisting of a Ti-photoelectric cell and filter radiometer, in which the photoelectric current, after amplification, is measured on a precision microammeter.

The $T i$-photoelectric cell responds only to wave lengths shorter than about $3400 \mathrm{~A}$. The filters used are opaque to wave lengths ranging from 2950 to $3100 \mathrm{~A}$. The spectral band measured therefore comprises: (a) the component transmitted by the filter, consisting of wave lengths between about 3100 and $3300 \mathrm{~A}$ that are affected but little by ozone absorption, and (b) the component intercepted by the 
filter, consisting of wave lengths shorter than about $3100 \mathrm{~A}$ that lie in the region of great absorption by ozone, and, hence, are easily affected by a change in concentration in (or the length of path through) the layer of ozone traversed by the solar rays. Moreover, the photoelectric cell is about 60 to 70 times more sensitive at $2900 \mathrm{~A}$ than in the region of $3300 \mathrm{~A}$, which is practically the long-wave-length limit of photoelectric response of the $T i$-cells used.

As a result of this high selective response of the photoelectric cell, a slight change in the amount of ozone in the path of the solar rays has an appreciable effect upon the atmospheric transmission of ultraviolet at 2900 to $3100 \mathrm{~A}$ and, hence, upon the percentage transmission of the filter, which increases with increase in the amount of ozone in the atmosphere.

Consequently, with the well-known increase in the amount of atmospheric ozone that occurs during a cyclonic (low pressure) disturbance, there should be (and is) observed an appreciable increase in the percentage transmission of the filter for a given air mass (say, $m=1.5$ ) relative to the value obtained on days of average barometric pressure. Similarly, as will be noted presently, with the relatively much smaller amount of ozone that is known to be present in an anticyclonic (high pressure) area there should be (and is) observed an appreciable decrease in the filter transmission relative to the value observed on days of average barometric pressure [30].

\section{MEASUREMENTS OF SKY RADIATION}

In the radiometric measurements of 1934 at Flagstaff, Ariz., it was found [8] that, in an angle of about $22^{\circ}$ surrounding the sun, the sky contributed about 0.3 to 0.4 percent to the total ultraviolet solar radiation measured. In connection with the stratosphere ultraviolet solar radiation measurements it was of interest to determine the amount of cloudless sky radiation relative to the total (sun + sky) that could enter the photoelectric cell. In the balloon ascensions the sky was never cloudless. Hence, the herein-described measurements are minimum values for an altitude of $7,300 \mathrm{ft}$-clouds near the sun would increase the amount of sky radiation.

The measurements of sky radiation were made with $C d$-photoelectric cell No. 38303, previously used in the stratosphere flight made on June 16, 1938 (see fig. 9). For this purpose the window of the photoelectric cell was covered with two diffusing screens (four fineground surfaces) of Corex- $A$ glass, over which was mounted an opaque shield with an opening $17 \mathrm{~mm}$ in diameter, shown (at $C x$ ) in figure 6, as used in the stratosphere flights.

For measuring sky radiation, the $C d$-photoelectric cell was mounted in a container without the protruding vestibule shown in figure 1 of a previous publication [8]. In this manner the interior of the photoelectric cell was exposed to the sky comprised in an angle of about $128^{\circ}$, as used in the stratosphere flights, and in contrast with an aperture of $22^{\circ}$, as the instrument is ordinarily used [8]. By means of black cardboard disks, 17 to $40 \mathrm{~mm}$ in diameter, supported at various heights above the window, the direct solar rays and, in some measurements, additional parts of the sky could be excluded from the photoelectric cell. By turning the photoelectric cell through $90^{\circ}$ (in the same azimuth), a measurement was obtained of the amount of 
sky radiation in a solid angle of about $128^{\circ}$, with its central axis directed at the antisolar point.

Measurements of ultraviolet sky radiation of wave lengths less than about $3300 \mathrm{~A}$ are depicted in figure 1. The data in the upper part, $A$, of the illustration were obtained by shadowing the opening of the photoelectric cell with a disk $18 \mathrm{~mm}$ in diameter situated $17 \mathrm{~cm}$ above the surface of the window. The air mass represents the solar height or column of air passed through by the directly incident solar rays.

The upper part, $A$, of figure 1, depicts the percentage of ultraviolet sky radiation relative to the total (sun plus sky) radiation incident upon the window of the photoelectric cell, exposed normal to the sun. For any given solar height (column of air traversed; air mass, say, $m=1.4)$, the ultraviolet sky radiation comprised in a solid angle of $128^{\circ}$

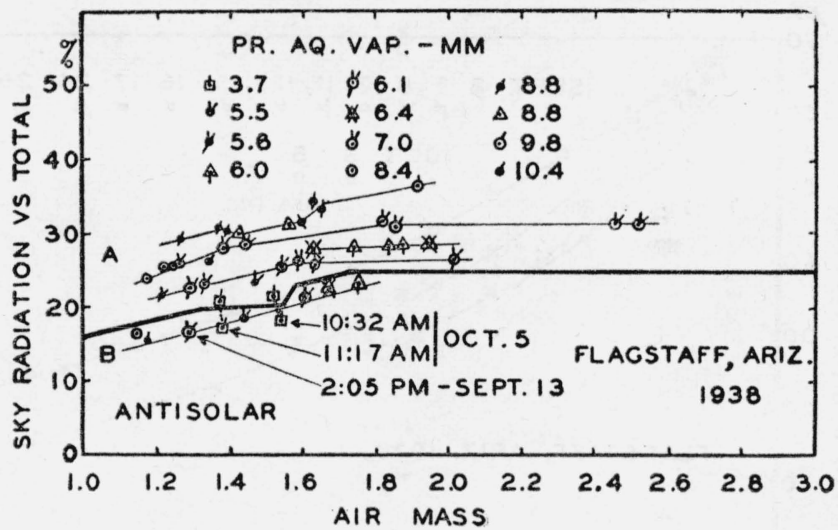

FIGURE 1.-Part A, ultraviolet sky radiation relative to the total incident (sun plus sky) radiation for different solar heights, $i$. e., column of air traversed by the directly incident solar rays; part $B$, ultraviolet sky radiation from the antisolar point, $i$. e., $90^{\circ}$ from the sun.

varies from 20 to 30 percent, depending upon scattering by dust particles, as indicated by the width of the corona around the sun, and, to some extent, upon the pressure of aqueous vapor (i. e., the amount of precipitable water), indicated at the top of figure 1 .

The lower part, $B$, of figure 1, gives the amount of ultraviolet sky radiation in a solid angle of $128^{\circ}$, centered on a point $90^{\circ}$ from, and in the same azimuth with, the sun (the antisolar point) compared with the amount of directly incident solar radiation (i. e., sun minus sky radiation mentioned in the preceding paragraph).

The sky radiation from the antisolar point is more uniform from day to day and in that respect less dependent upon atmospheric water vapor. The measurements at 10:32 a. m. and 11:17 a. m. on October 5 are interesting, because they were made between sets of filter-transmission measurements (fig. 3 ), with a $T i$-photoelectric cell having an opening of $22^{\circ}$ to the sky.

From the fact that the sky radiation on October 5 was the lowest observed during the course of the whole series of measurements, it appears that the high values of the filter transmissions depicted in figure 3 , and the total intensities in figure 2 , are affected but little by 
scattered ultraviolet radiation, as compared with the effect of variations of ozone in the stratosphere.

\section{DIURNAL VARIATION IN ULTRAVIOLET SOLAR RADIATION}

The present measurements of the total intensity and spectral quality (spectral-energy distribution) of ultraviolet solar radiation of short wave lengths were made with the photoelectric cell, $T i-1$, and filters used in 1934 [8]. The so-called rainy season seemed to continue longer and there appeared to be more cloudiness this year than during the same season 4 years ago. Measurements were therefore made only on the clearest days.

In figure 2 are depicted various measurements of total (integrated) intensities of ultraviolet solar radiation of wave lengths shorter than

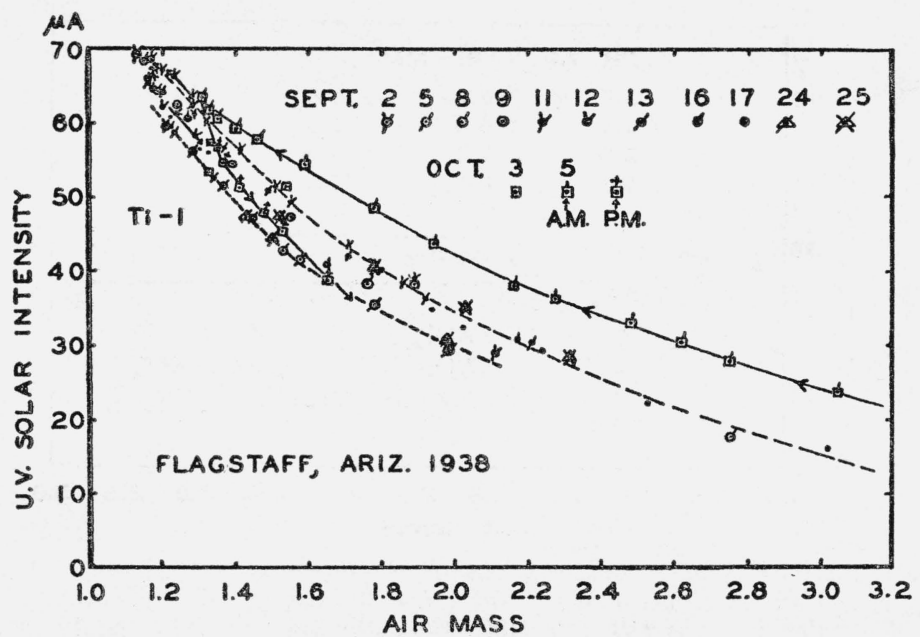

FIGURE 2.-Ultraviolet solar intensities on different dates, and different solar altitudes-air masses traversed by the directly incident rays.

about $3300 \mathrm{~A}$. The intensities are relative values; that is, deflections of the microammeter needle.

The main point of interest in these curves is that there is a tendency for the intensities observed on days of high barometric pressure to be higher than on days of average air pressure (see fig. 4). A notable example is the series of intensity measurements made on October 5, which, even for a large air mass $(m=3.05$ at 8:23 a. m.) was about 65 percent higher than the best values previously observed. However, by afternoon the intensities decreased to the lowest values observed during the season, in spite of the fact that (judged by the smallness of the solar corona) the sky continued to be clear and relatively free from nuclei. The reason therefore is to be found in the increase in ozone content, as interpreted from the filter transmission depicted in figure 5 .

In figure 3 are shown the transmissions of the four filters used $(B a-3, B a-1, N i$, and $C x-D$, previously described [8]) for various air masses traversed by the solar ultraviolet rays. The various symbols depict the transmissions on different days that may be identified by comparison with figure 4 . 
The accuracy attained in the measurements of the percentage transmissions of the filters is relatively high. That is to say, two sets of measurements, made in succession at intervals of 1 to 2 minutes,

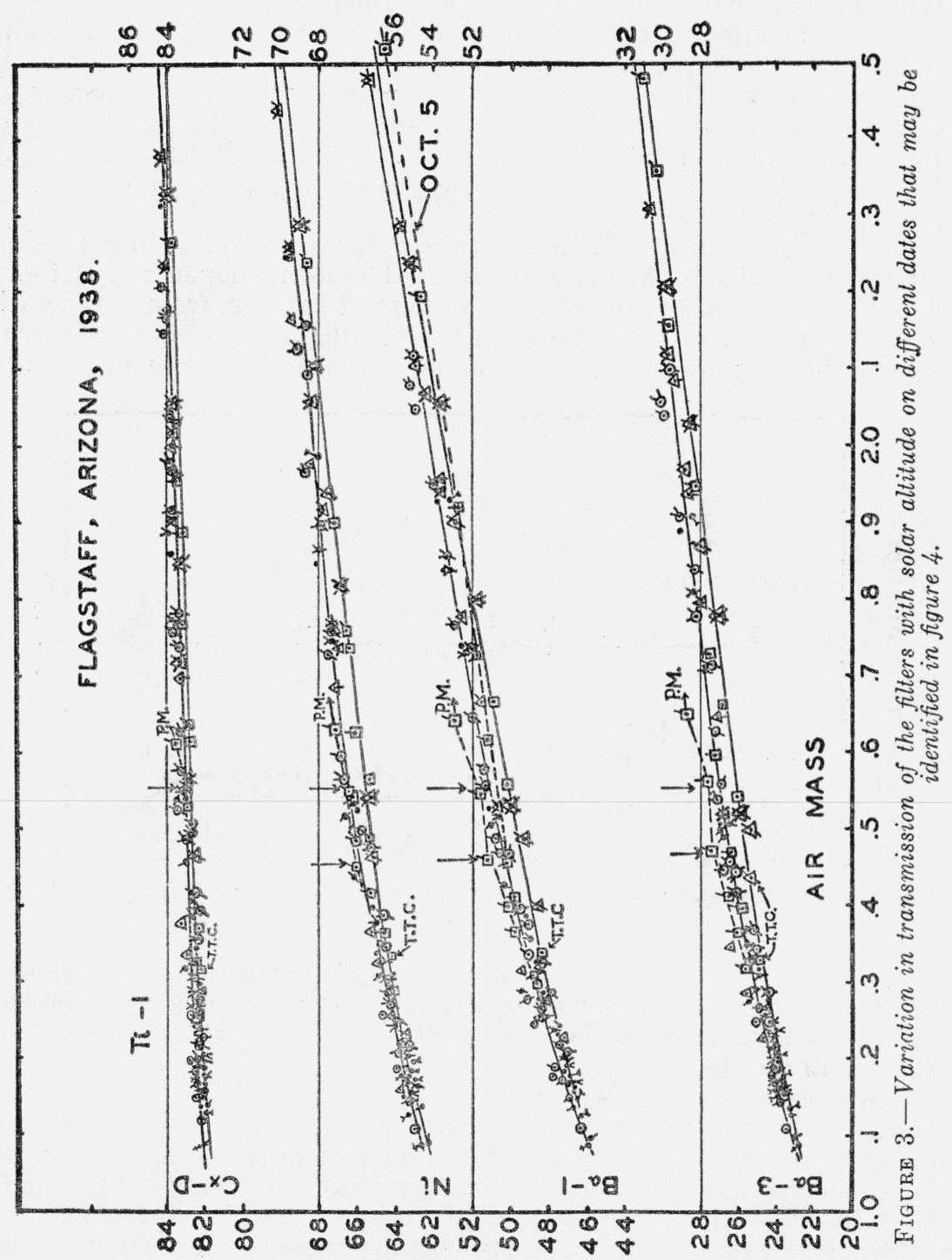

LNZJYId NI NOISSINSN甘Yd

differed by only 1 to 3 parts in 500 ; and this difference was frequently ascribable to a change (of only $\Delta m=0.01$ ) in the air mass traversed by the solar rays. The precision attained in the measurements is ascribable to improvements in the ultraviolet-intensity meter and to unusual 
meteorological conditions (uniform barometric pressure and a clear sky), which makes it possible to correlate the change in percentage transmission of a given filter (e. g., $B a-1$ ), from day to day, even though the numerical values differ by only a few percent.

It is to be noted that for any one filter the ultraviolet transmissions fall into two groups; the upper curve, as will be noticed in figure 4, belonging to average air pressures and the lower curve belonging to high barometric pressures. Variations in pressure of aqueous vapor, which ranged from 5 to $11 \mathrm{~mm}$, show no systematic effect upon the filter transmissions-partly because water vapor has no selective absorption in this spectral region.

The points marked T.T.C. represent measurements through thin cirrus clouds that suddenly appeared. The measurements of October 3 are especially noteworthy because part of the sky, from the zenith southward, became overcast with a thin diaphanous sheet of cirrus clouds, in long rolls ("corrugation in cirrus") that were practically

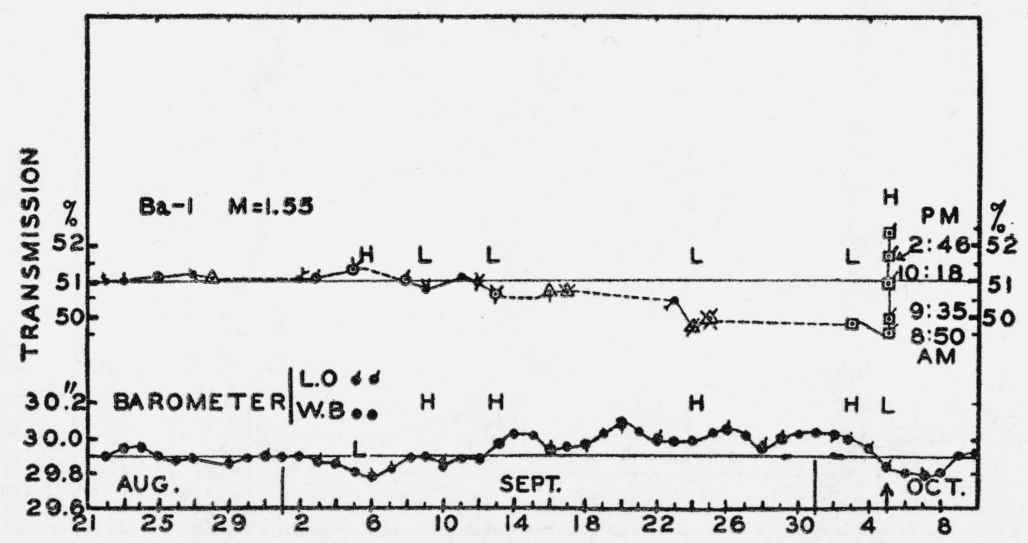

FigURE 4.-Graphs showing the percentage transmission of a certain filter $(B a-1)$, and the barometric pressure on different dates.

stationary for some 8 to 10 minutes; permitting a complete series of filter measurements, which show that (water) ice spicules have practically no selective absorption in the ultraviolet, as previously observed through a thin fog [8].

Most important are the filter transmissions on October 5, which were conspicuously low early in the forenoon (table 1) and gradually increased to high values in the afternoon (see dotted curve in fig. 3). The arrows show two series of measurements, indicating turbulence that continued for more than half an hour.

Since it requires from 7 to 10 minutes to complete a series of measurements with a set of four filters, and since all values in each series depart consistently in the same direction from the average curve, it appears that this irregularity in the measurements of October 5 is not caused by errors in observation. Incidentally, it is relevant to state that, each time, before making a set of measurements the filter was wiped with a soft linen cloth, or with a fine-haired brush, and examined in reflected light to ascertain that no dust or lint adhered to the surfaces (attracted by electrostatic charges - a common occurrence in a dry climate), thus reducing the percentage transmission. 
3. CORRELATION OF ATMOSPHERIC TRANSMISSION OF ULTRAVIOLET SOLAR RADIATION WITH BAROMETRIC PRESSURE

As noted on a preceding page, it is well established that a change in barometric pressure is accompanied by a change in the ozone content in the upper atmosphere; high ozone values accompanying low-pressure areas and vice versa. Hence, these variations in atmospheric ozone should affect the filter transmissions. That is to say, relatively higher filter transmissions should be observed when the barometric pressure is low, and vice versa.

In order to separate this effect from the variation in filter transmission with solar height (air mass traversed by the rays, depicted in fig. 3 ) it is necessary to compare the data for a particular air mass traversed by the rays. For the purpose of the present paper, an air mass of $m=1.55$ is used; or the solar height at 9:15 to 10:30 a. m. (MST), depending upon the time of the year.

In figure 4 the lower curve gives the barometer readings (in inches; reduced to sea level) on different dates. The atmospheric pressure data taken from the barograph record at the Lowell Observatory ("L. O."), which is at a somewhat higher elevation $(80 \mathrm{~m})$ than the U. S. Weather Bureau ("W. B."), are in good agreement with the mercurial barometer readings supplied by the Weather Bureau. The latter measurements are made at 5:30 a. m. (MST).

The upper curve in figure 4 gives the percentage transmission of the filter, $B a-1$, [8] for air mass $m=1.55$ on different dates. The particular titanium photoelectric cell used was $T i-1[8,21]$.

The point of interest in these two curves is that after September 1, when the so-called "rainy season" had practically terminated, there is a fairly systematic correlation of high barometer readings and low transmissions (marked " $H$ " and "L" in fig. 4) and vice versa; particularly after September 13, when the barometer continued relatively "high" (about 30.0 in.) until after October 3, 1938. During this time the filter transmissions remained conspicuously lower than the values obtained prior to September 12 and higher than the average for that time of the year [21]. Unfortunately, cloudy weather prevented making measurements during the time of high barometric pressures between September 26 and October 2.

While observations were in progress it was noted that on September 5 the filter transmissions were irregular- "high in a clear sky," except for a short while when they were low for $m=1.3$; and they were "low for $m=1.15$ to 1.5 -forenoon and afternoon" on September 9 . Since completion of the measurements a study has been made of these results, and as shown in figures 4 and 5 , the reason for these variations is apparent.

In his investigations of the variation in atmospheric ozone with meteorological conditions in the southwestern part of the United States, Kimball [12] has shown that, during the months of August and September, surface pressure conditions in Southern California are dominated almost continuously by a "Pacific high" and a "Yuma low" barometric-pressure area. Apparently, from the daily weather maps and from figure 4, this effect extends to Flagstaff, Ariz., where (during these measurements) the barometric pressure remained remarkably uniform, with only one small marked ("low") cyclonic disturbance, which arrived an hour or so in advance of the usual diurnal low on October 5. 
TABLE 1.-Filter transmissions of integrated ultraviolet solar radiation, using titanium photoelectric cell, Ti-1

[Filters: $B a-3=$ barium fint, thickness $3 \mathrm{~mm} ; B a-1$, same, thickness $1 \mathrm{~mm} ; N i=$ Nillite (trade name); $C x=$ Corex- $D$ (trade name); $T r=$ percentage transmission; $m=$ air mass; $\mu a=$ D (tre ate intensity with air mass; $p=$ pressure of aqueous vapor in the atmosphere. Observations at Flagstaff, Ariz. (Lat. $35^{\circ} 12^{\prime} \mathrm{N} ; \mathrm{Alt}$. 7,300 ft) in 1938.]

\begin{tabular}{|c|c|c|c|c|c|c|c|c|c|c|}
\hline 1 & 2 & 3 & 4 & 5 & 6 & 7 & 8 & 9 & 10 & 11 \\
\hline \multirow{2}{*}{ Date, 1938, and time } & \multirow{2}{*}{ Intensity } & \multicolumn{2}{|c|}{$B a-3$} & \multicolumn{2}{|c|}{$B a-1$} & \multicolumn{2}{|c|}{$\mathrm{Ni}$} & \multicolumn{2}{|c|}{$C x$} & \multirow{2}{*}{ Remarks } \\
\hline & & $m$ & $T r$ & $m$ & $T r$ & $m$ & $\operatorname{Tr}$ & $m$ & $T r$ & \\
\hline 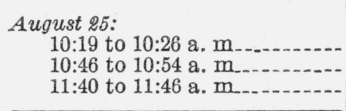 & $\begin{array}{l}\mu a \\
+56.3 \\
+59.7 \\
* 65.3\end{array}$ & $\begin{array}{r}1.25 \\
1.18 \\
* 1.11\end{array}$ & $\begin{array}{l}25.1 \\
24.2 \\
23.5\end{array}$ & $\begin{array}{l}1.25 \\
1.18 \\
1.11\end{array}$ & $\begin{array}{l}48.8 \\
47.7 \\
46.3\end{array}$ & $\begin{array}{l}1.26 \\
1.19 \\
1.11\end{array}$ & $\begin{array}{l}64.7 \\
63.8 \\
63.1\end{array}$ & $\begin{array}{r}\dagger 1.26 \\
\dagger 1.20 \\
1.12\end{array}$ & $\begin{array}{l}82.8 \\
82.8 \\
82.2\end{array}$ & $\begin{array}{l}p=8.38 \mathrm{~mm} \text { at } 12: 15 \mathrm{p} . \mathrm{m} . \text { Sky cloudless, small corona at } 10: 20 \\
\text { a. m. Fracto-cumulus near at 11:30 a. m. }\end{array}$ \\
\hline $\begin{array}{l}\text { August 27: } \\
\quad 9: 17 \text { to } 9: 25 \text { a. m- } \\
\text { 9:30 to } 9: 38 \text { a. m- } \\
\text { 10:04 to } 10: 14 \text { a. m- }\end{array}$ & $\begin{array}{l}\dagger 37.5 \\
+42.3 \\
+51.2\end{array}$ & $\begin{array}{r}1.50 \\
+1.42 \\
* 1.28\end{array}$ & $\begin{array}{l}27.1 \\
27.2 \\
25.5\end{array}$ & $\begin{array}{l}1.51 \\
1.43 \\
1.29\end{array}$ & $\begin{array}{l}51.1 \\
50.4 \\
49.5\end{array}$ & $\begin{array}{l}1.52 \\
1.44 \\
1.31\end{array}$ & $\begin{array}{l}66.7 \\
66.2 \\
65.0\end{array}$ & $\begin{array}{r}+1.54 \\
1.46 \\
1.32\end{array}$ & $\begin{array}{l}83.5 \\
83.2 \\
83.2\end{array}$ & $\begin{array}{l}\quad p=8.82 \mathrm{~mm} \text { at } 10: 55 \mathrm{a} . \mathrm{m} \text {. Large cumulus clouds on } \mathrm{S} \text { horizon } \\
\text { and fracto on } \mathrm{S} \text {. F. Peaks at 9:30 a. m. Sky overcast at 10:35; rain } \\
\text { at } 11: 15 \mathrm{a} . \mathrm{m} \text {. }\end{array}$ \\
\hline 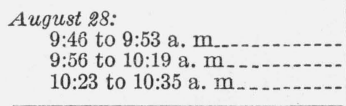 & $\begin{array}{l}\dagger 45.2 \\
+49.7 \\
+51.5\end{array}$ & $\begin{array}{r}1.35 \\
+1.28 \\
* 1.23\end{array}$ & $\begin{array}{l}26.4 \\
25.4 \\
24.7\end{array}$ & $\begin{array}{l}1.35 \\
1.32 \\
1.25\end{array}$ & $\begin{array}{l}50.3 \\
49.5 \\
48.5\end{array}$ & $\begin{array}{l}1.37 \\
1.33 \\
1.26\end{array}$ & $\begin{array}{l}65.3 \\
65.1 \\
64.3\end{array}$ & $\begin{array}{r}\dagger 1.38 \\
1.34 \\
1.26\end{array}$ & $\begin{array}{l}83.3 \\
83.0 \\
82.3\end{array}$ & $\begin{array}{l}\quad p=8.82 \mathrm{~mm} \text { at } 11: 45 \text { a. m. Fracto-cumuli on } \mathrm{S} \text { horizon, and } \\
\text { cumuli on S. F. Peaks at } 10 \text { a. m. Large cumuli near sun at } 10: 27 \\
\text { a. } \mathrm{m} \text {. }\end{array}$ \\
\hline $\begin{array}{l}\text { September } 2: \\
\text { 1:02 to } 1: 09 \text { p. m- } \\
\text { 1:20 to } 1: 27 \text { p. m- } \\
1: 42 \text { to } 1: 46 \text { p. m- }\end{array}$ & $\begin{array}{l}+69.3 \\
+68.7 \\
{ }^{*} 64.8\end{array}$ & $\begin{array}{r}1.13 \\
1.16 \\
* 1.18\end{array}$ & $\begin{array}{l}23.3 \\
23.9 \\
23.7\end{array}$ & $\begin{array}{l}1.13 \\
1.15 \\
1.18\end{array}$ & $\begin{array}{l}46.3 \\
46.5 \\
46.9\end{array}$ & $\begin{array}{l}1.13 \\
1.15 \\
1.18\end{array}$ & $\begin{array}{l}63.4 \\
63.3 \\
63.8\end{array}$ & $\begin{array}{r}+1.13 \\
+1.14 \\
1.18\end{array}$ & $\begin{array}{l}82.0 \\
82.3 \\
82.4\end{array}$ & $\begin{array}{l}p=10.4 \mathrm{~mm} \text { at } 3: 07 \text { p. m. Sky full of fracto-cumuli, except clear } \\
\text { area around the sun, angle } 40^{\circ} \text {. }\end{array}$ \\
\hline 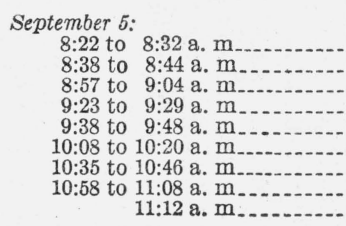 & $\begin{array}{l}\dagger 25.8 \\
* 29.7 \\
* 35.5 \\
+41.8 \\
* 47.3 \\
+51.2 \\
* 56.3 \\
+59.5\end{array}$ & $\begin{array}{r}2.06 \\
1.91 \\
* 1.78 \\
1.54 \\
* 1.45 \\
1.33 \\
1.25 \\
\dagger 1.21\end{array}$ & $\begin{array}{l}30.1 \\
29.1 \\
28.2 \\
27.1 \\
26.7 \\
25.2 \\
24.4 \\
24.1\end{array}$ & $\begin{array}{l}2.08 \\
1.95 \\
1.77 \\
1.56 \\
1.47 \\
1.34 \\
1.26 \\
1.22\end{array}$ & $\begin{array}{r}55.3 \\
54.1 \\
53.0 \\
51.3 \\
50.5 \\
49.2 \\
48.3 \\
47.4\end{array}$ & $\begin{array}{l}2.13 \\
1.97 \\
1.76 \\
1.57 \\
1.49 \\
1.35 \\
1.27 \\
1.22\end{array}$ & $\begin{array}{l}69.2 \\
68.9 \\
67.4 \\
66.8 \\
66.1 \\
64.5 \\
64.2 \\
63.7\end{array}$ & $\begin{array}{r}\dagger 2.17 \\
* 1.98 \\
1.74 \\
+1.58 \\
1.50 \\
+1.36 \\
{ }^{*} 1.28 \\
1.23 \\
\quad 1.20\end{array}$ & $\begin{array}{l}84.2 \\
84.0 \\
83.4 \\
83.3 \\
82.7 \\
82.4 \\
82.3 \\
82.3 \\
82.5\end{array}$ & $\begin{array}{l}p=7.0 \mathrm{~mm} \text { at } 11: 30 \text { a. m. Sky cloudless; light } \mathrm{W} \text { breeze at } 8: 15 \\
\text { a. m. Clouds on } \mathrm{S} \text {. F. Peaks at 9:05 a. m.; extend } \mathrm{E} \text { past The Elden } \\
\text { at } 10: 20 \text { a. m. Fracto-cumulus forming in } \mathrm{S} \text { and } \mathrm{SW} \text { at 10:50 a. m.; } \\
\text { over sun at } 11: 20 \mathrm{a} \text {. } \mathrm{m} \text {. }\end{array}$ \\
\hline
\end{tabular}




\begin{tabular}{|c|c|c|c|c|c|c|c|c|c|c|}
\hline 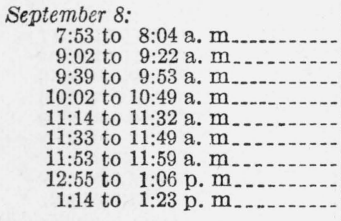 & $\begin{array}{l}\dagger 17.5 \\
* 38.2 \\
\dagger 42.5 \\
* 60.4 \\
+64.1 \\
* 65.8 \\
+68.2 \\
* 62.5 \\
+64.3\end{array}$ & $\begin{array}{r}2.60 \\
1.63 \\
1.46 \\
* 1.27 \\
\dagger 1.19 \\
* 1.16 \\
\dagger 1.15 \\
* 1.16 \\
\dagger 1.18\end{array}$ & $\begin{array}{l}32.9 \\
27.2 \\
26.5 \\
24.8 \\
24.1 \\
23.7 \\
23.8 \\
23.9 \\
24.1\end{array}$ & $\begin{array}{l}2.65 \\
\text { 1. } 65 \\
\text { 1. } 49 \\
\text { 1. } 28 \\
\text { 1. } 19 \\
\text { 1. } 17 \\
\text { 1. } 16 \\
1.18\end{array}$ & $\begin{array}{l}58.7 \\
52.1 \\
50.8 \\
49.2 \\
47.6 \\
47.0 \\
46.8 \\
46.9 \\
47.3\end{array}$ & $\begin{array}{l}2.70 \\
\text { 1. } 73 \\
\text { 1. } 50 \\
\text { 1. } 29 \\
1.18 \\
\text { 1. } 16 \\
\text { 1. } 15 \\
\text { 1. } 17\end{array}$ & $\begin{array}{l}71.2 \\
67.6 \\
65.8 \\
64.3 \\
63.8 \\
63.5 \\
63.4 \\
63.3 \\
63.8\end{array}$ & $\begin{array}{r}\dagger 2.75 \\
+1.76 \\
\dagger 1.53 \\
1.42 \\
1.22 \\
1.19 \\
1.16 \\
1.15 \\
1.17\end{array}$ & $\begin{array}{l}85.3 \\
83.7 \\
83.4 \\
82.6 \\
82.3 \\
82.5 \\
82.1 \\
82.6 \\
82.4\end{array}$ & $\begin{array}{l}p=8.0 \mathrm{~mm} \text { at } 12: 12 \mathrm{p} . \mathrm{m} \text {. Sky cloudless at } 8 \mathrm{a} \text {. m.; numerous fracto } \\
\text { at } 9: 30 \text { to } 10 \text { a. m.; cloudless but faintly murky at } 10: 30 \text {; cirrus haze } \\
\text { at } 11: 55 \text { a. m.; faint murky haze, in waves, at } 1 \mathrm{p} \text {. m.; sky covered } \\
\text { with large fracto after } 1: 30 \mathrm{p} \text {. } \mathrm{m} \text {. }\end{array}$ \\
\hline 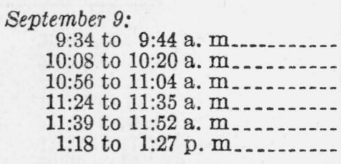 & $\begin{array}{l}{ }^{*} 47.3 \\
\dagger 54.3 \\
* 62.2 \\
+56.3 \\
* 58.4 \\
\dagger 54.0\end{array}$ & $\begin{array}{r}1.51 \\
\text { *. } 35 \\
1.24 \\
\text { *1. } 19 \\
\dagger 1.19\end{array}$ & $\begin{array}{l}26.5 \\
25.4 \\
24.1 \\
24.0 \\
24.0 \\
24.2\end{array}$ & $\begin{array}{l}\text { 1. } 52 \\
\text { 1. } 36 \\
1.25 \\
\text { 1. } 19 \\
1.17 \\
\text { 1. } 19\end{array}$ & $\begin{array}{l}50.7 \\
49.1 \\
47.4 \\
47.2 \\
46.6 \\
47.5\end{array}$ & $\begin{array}{l}\text { 1. } 54 \\
\text { 1. } 38 \\
\text { 1. } 25 \\
\text { 1. } 18 \\
\text { 1. } 18\end{array}$ & $\begin{array}{l}66.2 \\
65.2 \\
64.0 \\
63.0 \\
62.8 \\
63.3\end{array}$ & $\begin{array}{r}* 1.55 \\
\dagger 1.39 \\
1.26 \\
\dagger 1.21 \\
1.18 \\
1.18\end{array}$ & $\begin{array}{l}83.2 \\
82.7 \\
83.4 \\
82.3 \\
82.2 \\
82.3\end{array}$ & $\begin{array}{l}p=5.5 \mathrm{~mm} \text { at } 12: 02 \mathrm{p} \text {. } \mathrm{m} \text {. Sky faintly murky at } 10 \mathrm{a} \text {. m.; large } \\
\text { fracto clouds at 11:20 to } 11: 50 \text { a. m.; fracto-cumulus clouds and smoke } \\
\text { at } 1: 27 \mathrm{p} \text {. m. Filter transmission low for } m=1.15 \text { to } 1.5 \text {, as on } \\
\text { September } 5 \text {. }\end{array}$ \\
\hline 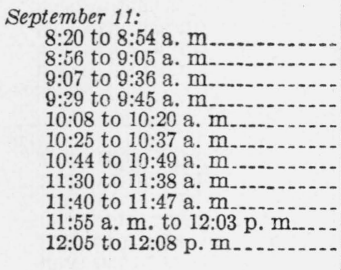 & $\begin{array}{l}\dagger 28.8 \\
* 38.4 \\
\dagger 49.7 \\
* 51.3 \\
\dagger 56.5 \\
* 60.2 \\
+62.3 \\
* 67.2 \\
+67.7 \\
+67.5 \\
+67.3\end{array}$ & $\begin{array}{r}1.89 \\
1.79 \\
+1.55 \\
1.51 \\
1.37 \\
+1.32 \\
+1.28 \\
1.20 \\
+1.18 \\
1.17 \\
1.16\end{array}$ & $\begin{array}{l}29.3 \\
28.0 \\
27.5 \\
27.0 \\
25.7 \\
24.9 \\
24.5 \\
24.1 \\
23.8 \\
23.8 \\
23.7\end{array}$ & $\begin{array}{l}1.93 \\
1.84 \\
1.74 \\
1.52 \\
1.39 \\
1.33 \\
1.29 \\
1.20 \\
1.19 \\
1.17 \\
1.16\end{array}$ & $\begin{array}{l}53.9 \\
53.6 \\
52.7 \\
51.3 \\
49.2 \\
48.8 \\
48.3 \\
47.3 \\
46.8 \\
46.8 \\
46.8\end{array}$ & $\begin{array}{l}2.25 \\
1.85 \\
1.76 \\
1.53 \\
1.40 \\
1.34 \\
1.30 \\
1.19 \\
1.18 \\
1.17 \\
1.16\end{array}$ & $\begin{array}{l}69.8 \\
68.3 \\
67.7 \\
66.0 \\
65.3 \\
65.1 \\
64.4 \\
63.5 \\
63.4 \\
63.4 \\
63.7\end{array}$ & $\begin{array}{r}\dagger 2.32 \\
* 1.86 \\
1.77 \\
1.55 \\
\dagger 1.41 \\
1.35 \\
1.30 \\
* 1.21 \\
1.19 \\
* 1.16 \\
\dagger 1.16\end{array}$ & \begin{tabular}{l|}
84.5 \\
83.9 \\
83.6 \\
83.1 \\
82.7 \\
82.5 \\
82.4 \\
82.0 \\
82.1 \\
82.0 \\
82.2
\end{tabular} & $\begin{array}{l}p=7.2 \mathrm{~mm} \text { at } 12: 25 \mathrm{p} . \mathrm{m} \text {. Small corona. Sky cloudless until } \\
\text { 10:30 a. m. Then fracto-cumulus on horizon. Murky cirrus haze } \\
\text { at } 11: 55 \mathrm{a} . \mathrm{m} \text {.; stopped at } 12.08 \mathrm{p} \text {. m. by fracto- cumulus cloud ex- } \\
\text { tending from sun to } \mathrm{SW} \text { horizon. }\end{array}$ \\
\hline
\end{tabular}

.

1:55 to

eptember 9:

9:34 to $9: 44 \mathrm{a} . \mathrm{m}$

$10: 56$ to $11: 04 \mathrm{a} . \mathrm{m}$

$11: 24$ to $11: 35 \mathrm{a}$.

$1: 18$ to $1: 27 \mathrm{p}, \mathrm{m}$

\begin{tabular}{l|l|l}
1.16 & 63.7 & $\dagger 1.16$
\end{tabular} 
TABLE 1.-Filter transmissions of integrated ultraviolet solar radiation, using titanium photoelectric cell, Ti-1-Continued

\begin{tabular}{|c|c|c|c|c|c|c|c|c|c|c|}
\hline 1 & 2 & 3 & 4 & 5 & 6 & 7 & 8 & 9 & 10 & 11 \\
\hline \multirow{2}{*}{ Date, 1938 , and time } & \multirow{2}{*}{ Intensity } & \multicolumn{2}{|c|}{$B a-3$} & \multicolumn{2}{|c|}{$B a-1$} & \multicolumn{2}{|c|}{$\mathrm{Ni}$} & \multicolumn{2}{|c|}{$C x$} & \multirow{2}{*}{ Remarks } \\
\hline & & $m$ & $T r$ & $m$ & $\operatorname{Tr}$ & $m$ & $\operatorname{Tr}$ & $m$ & $T r$ & \\
\hline 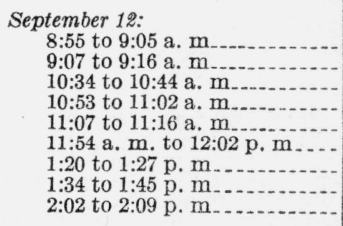 & \begin{tabular}{c|}
$\mu \mathrm{a}$ \\
+39.2 \\
$* 43.3$ \\
+61.8 \\
$* 63.5$ \\
+66.3 \\
$* 66.5$ \\
+62.2 \\
$* 61.3$ \\
+58.0
\end{tabular} & $\begin{array}{r}1.81 \\
* 1.71 \\
\dagger 1.31 \\
1.26 \\
\dagger 1.23 \\
{ }^{1} 1.17 \\
1.20 \\
{ }^{*} 1.24 \\
\dagger 1.29\end{array}$ & $\begin{array}{l}28.3 \\
27.8 \\
24.9 \\
24.6 \\
24.2 \\
23.6 \\
24.1 \\
24.6 \\
25.2\end{array}$ & $\begin{array}{l}1.84 \\
1.73 \\
1.32 \\
1.27 \\
1.24 \\
1.17 \\
1.20 \\
1.23 \\
1.28\end{array}$ & $\begin{array}{l}53.3 \\
52.5 \\
48.5 \\
48.1 \\
47.7 \\
46.8 \\
47.3 \\
47.8 \\
48.7\end{array}$ & $\begin{array}{l}1.87 \\
1.75 \\
1.33 \\
1.27 \\
1.25 \\
1.18 \\
1.20 \\
1.22 \\
1.28\end{array}$ & $\begin{array}{l}68.2 \\
67.5 \\
64.8 \\
64.1 \\
63.7 \\
62.8 \\
63.4 \\
64.9 \\
64.2\end{array}$ & $\begin{array}{r}\dagger 1.89 \\
1.78 \\
1.30 \\
* 1.28 \\
1.25 \\
1.18 \\
\dagger 1.20 \\
1.21 \\
1.27\end{array}$ & \begin{tabular}{l|}
84.1 \\
83.8 \\
82.6 \\
82.4 \\
82.3 \\
82.1 \\
82.3 \\
82.5 \\
82.7
\end{tabular} & $\begin{array}{l}p=5.6 \mathrm{~mm} \text { at } 12: 10 \mathrm{p} . \mathrm{m} \text {. Sky cloudless; deep blue; small corona } \\
\text { until } 11: 30 \mathrm{a} \text {. m. Hazy around sun at } 11: 55 \mathrm{a} \text {. m. Fine haze in } \\
\text { zenith at } 1: 15 \mathrm{p} \text {. m. Thin cirrus haze } \mathrm{SW} \text { of sun at } 1: 45 \mathrm{p} \text {. m.; } \\
\text { formed into small fracto at } 1: 47 \mathrm{p} . \mathrm{m} \text {. Sky murky around sun at } \\
\text { 1:55 p. m.; clear at } 2: 05 \mathrm{p} . \mathrm{m} \text {. }\end{array}$ \\
\hline 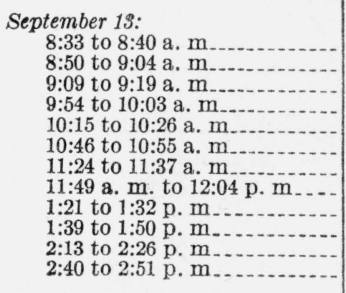 & $\begin{array}{l}* 30.6 \\
\dagger 36.3 \\
* 42.2 \\
\dagger 50.8 \\
* 56.8 \\
\dagger 61.2 \\
* 64.4 \\
\dagger 65.3 \\
* 59.8 \\
+58.8 \\
* 52.4 \\
\dagger 47.8\end{array}$ & $\begin{array}{r}2.10 \\
1.85 \\
* 1.71 \\
1.45 \\
* 1.37 \\
\dagger 1.29 \\
1.20 \\
+1.16 \\
* 1.22 \\
1.25 \\
* 1.34 \\
\dagger 1.42\end{array}$ & $\begin{array}{l}29.6 \\
28.3 \\
27.4 \\
26.1 \\
25.3 \\
24.4 \\
24.1 \\
23.7 \\
24.0 \\
24.7 \\
25.2 \\
26.0\end{array}$ & $\begin{array}{l}2.12 \\
1.86 \\
1.74 \\
1.47 \\
1.38 \\
1.29 \\
1.21 \\
1.17 \\
1.21 \\
1.24 \\
1.33 \\
1.40\end{array}$ & $\begin{array}{l}55.1 \\
53.3 \\
52.1 \\
50.2 \\
49.2 \\
47.8 \\
47.0 \\
46.7 \\
47.1 \\
47.7 \\
48.4 \\
49.6\end{array}$ & $\begin{array}{l}2.16 \\
1.90 \\
1.76 \\
1.48 \\
1.39 \\
1.30 \\
1.22 \\
1.18 \\
1.21 \\
1.24 \\
1.31 \\
1.39\end{array}$ & $\begin{array}{l}68.8 \\
68.0 \\
67.4 \\
65.4 \\
64.7 \\
64.4 \\
63.4 \\
63.0 \\
63.1 \\
63.3 \\
64.2 \\
64.8\end{array}$ & $\begin{array}{r}{ }^{*} 2.21 \\
\dagger 1.92 \\
1.78 \\
\dagger 1.49 \\
1.40 \\
1.31 \\
*_{1} .23 \\
1.18 \\
1.20 \\
\dagger 1.23 \\
1.30 \\
1.38\end{array}$ & $\begin{array}{l}84.4 \\
83.9 \\
83.4 \\
83.1 \\
82.4 \\
82.6 \\
82.2 \\
82.3 \\
82.3 \\
82.2 \\
82.4 \\
82.3\end{array}$ & $\begin{array}{l}p=6.1 \mathrm{~mm} \text { at } 12: 15 \mathrm{p} . \mathrm{m} . \mathrm{Sky} \text { cloudless; small corona; light } \\
\text { breeze from ESE; fracto low on } \mathrm{S} \text { horizon. In afternoon, corona } \\
\text { wider; sky more hazy; long wisps of fracto } \mathrm{SW} \text { and } \mathrm{NW} \text { of sun at } \\
2: 50 \mathrm{p} . \mathrm{m} \text {. }\end{array}$ \\
\hline 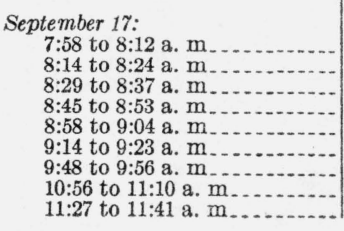 & $\begin{array}{l}* 16.3 \\
\dagger 22.4 \\
* 29.2 \\
+32.4 \\
* 35.3 \\
\dagger 40.1 \\
* 46.2 \\
+56.5 \\
{ }^{*} 60.8\end{array}$ & $\begin{array}{r}* 3.02 \\
\dagger 2.52 \\
2.31 \\
2.10 \\
* 1.97 \\
1.80 \\
* 1.52 \\
1.27 \\
* 1.22\end{array}$ & $\begin{array}{l}34.4 \\
32.4 \\
30.6 \\
29.6 \\
28.8 \\
27.9 \\
26.7 \\
24.7 \\
24.2\end{array}$ & $\begin{array}{l}2.84 \\
2.48 \\
2.29 \\
2.07 \\
1.95 \\
1.78 \\
1.53 \\
1.28 \\
1.23\end{array}$ & $\begin{array}{l}57.7 \\
57.3 \\
55.8 \\
54.5 \\
53.6 \\
52.5 \\
50.7 \\
48.3 \\
47.3\end{array}$ & $\begin{array}{l}2.70 \\
2.44 \\
2.26 \\
2.06 \\
1.92 \\
1.75 \\
1.54 \\
1.29 \\
1.23\end{array}$ & $\begin{array}{l}71.3 \\
70.2 \\
69.6 \\
68.4 \\
67.8 \\
67.0 \\
66.2 \\
64.2 \\
63.5\end{array}$ & $\begin{array}{r}2.60 \\
2.38 \\
* 2.24 \\
\dagger 2.02 \\
1.90 \\
\dagger 1.72 \\
1.55 \\
\dagger 1.30 \\
1.24\end{array}$ & $\begin{array}{l}85.1 \\
84.3 \\
84.2 \\
83.8 \\
83.7 \\
83.3 \\
82.9 \\
82.3 \\
82.2\end{array}$ & $\begin{array}{l}p=5.6 \mathrm{~mm} \text { at } 11: 55 \mathrm{a} . \mathrm{m} \text {. Sky cloudless, deep blue; small corona. } \\
\text { smoke from train at } 9: 56 \mathrm{a} \text {. m. Fracto-cumulus clouds begin form- } \\
\text { ing on } \mathrm{S} \text {. F. Peaks at } 10 \mathrm{a} \text {. } \mathrm{m} \text {.; spread } \mathrm{E} \text { and } \mathrm{W} \text {; cover } 50 \text { percent } \\
\text { of sky at } 11 \mathrm{a} . \mathrm{m} \text {. }\end{array}$ \\
\hline
\end{tabular}




\begin{tabular}{|c|c|c|c|c|c|c|c|c|c|c|}
\hline 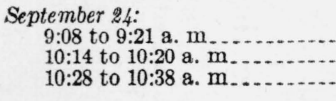 & $\begin{array}{l}\dagger 30.8 \\
* 44.5 \\
\dagger 47.5\end{array}$ & $\begin{array}{r}1.87 \\
* 1.50 \\
\dagger 1.44\end{array}$ & $\begin{array}{l}28.0 \\
25.3 \\
25.6\end{array}$ & $\begin{array}{l}1.90 \\
1.49 \\
1.40\end{array}$ & $\begin{array}{l}53.1 \\
49.3 \\
48.5\end{array}$ & $\begin{array}{l}1.94 \\
1.48 \\
-1 .-2\end{array}$ & $\begin{array}{l}67.7 \\
65.3\end{array}$ & $\begin{array}{r}+1.98 \\
1.47 \\
\hdashline\end{array}$ & $\begin{array}{l}83.8 \\
82.6 \\
-.-\end{array}$ & $\begin{array}{l}p=5.2 \mathrm{~mm} \text { at } 10: 50 \mathrm{a} . \mathrm{m} \text {. Sky cloudless but murky; wide white } \\
\text { corona at } 9 \mathrm{a} \text {. } \mathrm{m} \text {. Third series (10:28 to } 38 \text { a. m.) observed through } \\
\text { thin clouds }- \text {-showing nonselective absorption of ultraviolet. }\end{array}$ \\
\hline $\begin{array}{l}\text { September } 25: \\
8: 40 \text { to } 8: 50 \text { a. m.... } \\
8: 56 \text { to } 9: 06 \text { a. m } \\
9: 23 \text { to } 9: 30 \text { a. m..... } \\
10: 03 \text { to } 10: 12 \text { a. m }\end{array}$ & $\begin{array}{l}\dagger 28.3 \\
* 35.0 \\
\dagger 40.6 \\
* 47.5\end{array}$ & $\begin{array}{r}2.21 \\
2.03 \\
\dagger 1.78 \\
* 1.52\end{array}$ & $\begin{array}{l}29.8 \\
28.6 \\
27.1 \\
25.9\end{array}$ & $\begin{array}{l}2.24 \\
\text { 2. } 06 \\
\text { 1. } 80 \\
\text { 1. } 53\end{array}$ & $\begin{array}{l}55.3 \\
53.6 \\
51.8 \\
50.2\end{array}$ & $\begin{array}{l}2.29 \\
2.10 \\
1.82 \\
1.55\end{array}$ & $\begin{array}{l}69.0 \\
68.2 \\
66.8 \\
65.3\end{array}$ & $\begin{array}{r}\dagger 2.33 \\
2.14 \\
1.85 \\
1.57\end{array}$ & $\begin{array}{l}84.0 \\
83.8 \\
83.3 \\
83.1\end{array}$ & $\begin{array}{l}p=6.4 \mathrm{~mm} \text { at } 10: 25 \mathrm{a} . \mathrm{m} \text {. Sky cloudless, no smoke; small corona } \\
\text { at } 8: 45 \mathrm{a} \text {. m. Sky murking rapidly in } \mathrm{SW} \text { at } 10: 05 \mathrm{a} \text {. m. Thin } \\
\text { fracto-cirrus around sun, and cumulus rising in } \mathrm{SW} \text { at } 10: 15 \mathrm{a} \text {. m. }\end{array}$ \\
\hline $\begin{array}{l}\text { October } s: \\
9: 34 \text { to } 10: 06 \text { a. m } \\
10: 10 \text { to } 10: 26 \mathrm{a} . \mathrm{m} \\
11: 28 \text { to } 11: 38 \mathrm{a} . \mathrm{m} \\
1: 01 \text { to } 1: 09 \mathrm{p} . \mathrm{m} \\
1: 27 \text { to } 1: 34 \mathrm{p} . \mathrm{m}\end{array}$ & $\begin{array}{l}\mu 8 \\
\dagger 38.5 \\
+51.7 \\
+56.6 \\
+55.8 \\
+53.0\end{array}$ & $\begin{aligned} 1.65 \\
+1.54 \\
+1.33 \\
1.30 \\
\dagger 1.33\end{aligned}$ & $\begin{array}{l}26.9 \\
26.1 \\
25.1 \\
25.3 \\
25.7\end{array}$ & $\begin{array}{l}1.67 \\
\text { 1. } 56 \\
\text { 1. } 34 \\
\text { 1. } 30 \\
\text { 1. } 33\end{array}$ & $\begin{array}{l}51.0 \\
50.3 \\
48.5 \\
48.8 \\
48.8\end{array}$ & $\begin{array}{l}\text { 1. } 74 \\
1.57 \\
\text { 1. } 34 \\
\text { 1. } 30 \\
\text { 1. } 32\end{array}$ & $\begin{array}{l}66.5 \\
65.4 \\
64.3 \\
64.3 \\
64.4\end{array}$ & $\begin{array}{r}\dagger 1.89 \\
1.62 \\
1.35 \\
{ }^{*} 1.30 \\
1.32\end{array}$ & $\begin{array}{l}83.3 \\
82.8 \\
82.6 \\
82.2 \\
82.3\end{array}$ & $\begin{array}{l}\quad p=5.1 \mathrm{~mm} \text { at } 12: 50 \mathrm{p} . \mathrm{m} \text {. Sky cloudless; small corona; SE breeze } \\
\text { at start. Third series (11:30 a. m.) observed through thin, billowy } \\
\text { cirrus clouds. Thin haze over sun at } 1: 09 \mathrm{p} \text {. m. (Ba-s). Cloudy } \\
\text { p. m. }\end{array}$ \\
\hline 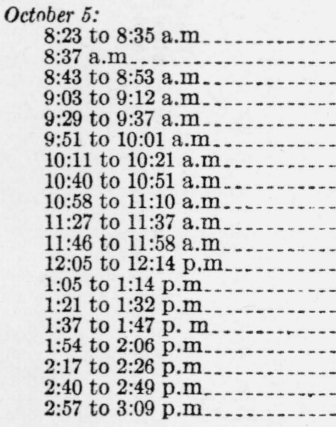 & $\begin{array}{l}\dagger 23.5 \\
* 28.0 \\
\dagger 33.2 \\
* 38.3 \\
\dagger 43.8 \\
* 48.6 \\
\dagger 54.3 \\
* 57.7 \\
\dagger 59.2 \\
\star^{*} 60.4 \\
\dagger 61.5 \\
* 63.8 \\
\dagger 61.8 \\
* 57.2 \\
\dagger 54.7 \\
* 51.5 \\
\dagger 47.8 \\
* 45.3 \\
\dagger 38.8\end{array}$ & $\begin{array}{l}\dagger 3.05 \\
* 2.75 \\
\dagger 2.48 \\
* 2.16 \\
\dagger 1.94 \\
1.72 \\
+1.59 \\
* 1.46 \\
+1.40 \\
* 1.35 \\
1.32 \\
* 1.31 \\
1.32 \\
+1.34 \\
+1.37 \\
+1.41 \\
\dagger 1.47 \\
1.56 \\
\dagger 1.65\end{array}$ & $\begin{array}{l}34.3 \\
32.0 \\
31.0 \\
29.7 \\
28.3 \\
27.8 \\
27.2 \\
26.5 \\
25.8 \\
25.6 \\
25.3 \\
25.3 \\
25.4 \\
25.8 \\
25.8 \\
26.4 \\
27.4 \\
27.6 \\
28.7\end{array}$ & $\begin{array}{l}2.90 \\
2.52 \\
2.20 \\
1.92 \\
1.73 \\
1.62 \\
1.47 \\
1.41 \\
1.35 \\
1.33 \\
1.31 \\
1.32 \\
1.34 \\
1.36 \\
1.40 \\
1.46 \\
1.55 \\
1.64\end{array}$ & \begin{tabular}{l|}
58.3 \\
-56.6 \\
54.8 \\
52.8 \\
51.8 \\
51.3 \\
50.3 \\
49.8 \\
49.3 \\
49.2 \\
48.8 \\
48.8 \\
49.3 \\
49.8 \\
50.1 \\
51.3 \\
51.6 \\
53.1
\end{tabular} & $\begin{array}{l}2.85 \\
2.58 \\
2.24 \\
1.90 \\
1.76 \\
1.63 \\
1.49 \\
1.42 \\
1.36 \\
1.34 \\
1.32 \\
1.32 \\
1.33 \\
1.36 \\
1.39 \\
1.44 \\
1.54 \\
1.63\end{array}$ & \begin{tabular}{l}
70.4 \\
\hdashline 69.8 \\
68.7 \\
67.3 \\
66.9 \\
66.2 \\
65.6 \\
65.4 \\
64.5 \\
64.3 \\
64.5 \\
64.3 \\
64.9 \\
64.8 \\
65.3 \\
65.9 \\
66.2 \\
67.1
\end{tabular} & \begin{tabular}{r}
2.80 \\
\hdashline 2.62 \\
2.27 \\
1.96 \\
$* 1.78$ \\
1.64 \\
1.50 \\
1.43 \\
1.37 \\
+1.34 \\
1.32 \\
+1.31 \\
1.33 \\
1.35 \\
1.38 \\
1.43 \\
$* 1.53$ \\
1.61
\end{tabular} & $\begin{array}{l}84.5 \\
84.2 \\
83.8 \\
83.7 \\
83.4 \\
82.8 \\
82.7 \\
82.6 \\
82.6 \\
82.4 \\
82.7 \\
82.3 \\
82.5 \\
82.7 \\
83.0 \\
82.8 \\
82.9 \\
83.4\end{array}$ & 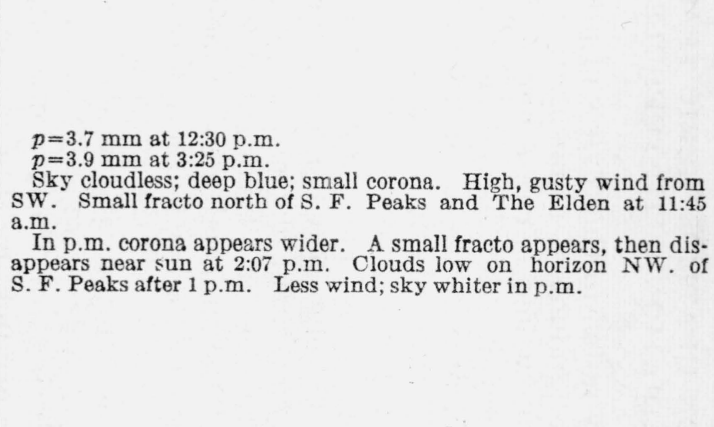 \\
\hline
\end{tabular}




\section{VARIATION IN ATMOSPHERIC TRANSMISSION OF ULTRAVIOLET SOLAR RADIATION WITH TURBULENCE IN THE OZONE LAYER}

As already noted in the review of previous observations on the variation of the amount of atmospheric ozone with weather conditions, it is uncertain which is cause and which is effect [16]. Presumably the variations in the filter-transmission measurements made on September 5, and in the measurements of 1934 [8], were caused by turbulence in atmospheric ozone.

In connection with the question of convection and turbulence in the ozone layer, the most important and far-reaching results were obtained on October 5, when a barographic "low" was registered at 4 a. m. ${ }^{4}$ and continued (excepting the usual slight rise to a maximum, between 10 to 11 a. m.) throughout the next 3 days.

In view of the unusual measurements obtained on this date, it is relevant to include a brief description of meteorological conditions on October 5. During all the preceding measurements, there had been but little wind; only light breezes from the south or southwest. On October 5 there was a strong, at times gusty, wind from the southwest (or SSW) during the greater part of the day. At the start (8:20 a. m.) and continuing until noon, the corona of scattered light around the sun was exceedingly small. By 1:30 p. m. the coronal scattering seemed wider, and by 2 p. m. the sky near the sun was conspicuously whiter. Small fracto clouds appeared in the east by $3 \mathrm{p}$. m., and the measurements were then terminated.

Evidently conditions in the stratosphere had been changing imperceptibly all day. This is shown by the filter transmissions. If it had been simply a question of the condition of the sky, as it appeared to the eye, then the filter transmissions on the afternoon of October 5 should have been below, instead of above, the average of the season.

At the start $(8: 20 \mathrm{a} . \mathrm{m}$.), the filter transmissions were, for the same air mass, about the same as observed on October 3. But by 10:50 a. $\mathrm{m}$. the transmissions had increased to the average, and by $3 \mathrm{p.m}$. the concentration of ozone had increased to such an extent that the filter transmissions greatly exceeded all values previously observed through that air mass $(m=1.65)$.

In figure 4 the filter transmissions of October 5 indicated at 8:50 and 9:35 a. m. (MST) represent the values that would have been observed through an air mass, $m=1.55$ (at 10:30 a. m.) if, in the meantime, in each case, the amount of ozone had remained the same as at the time when the measurement was made (i. e., through air masses $m=2.5$ and $m=1.9$, respectively-see fig. 3 ). The point depicted at $2: 46 \mathrm{p}$. $\mathrm{m}$. was observed through an air mass $m=1.55$ (table 1). It shows the rapid increase in ozone in the same air mass since 10:30 a. $\mathrm{m}$. The highest point, 52.5 percent, was observed at $3: 05 \mathrm{p}$. $\mathrm{m}$. (actual value, 53.1 percent; $m=1.64$ ). Incidentally, it is relevant to note (table 1) that the pressure of aqueous vapor (amount of precipitable water) was low and changed but little during these measurements.

"The diurnal variation in air pressure is much smaller in magnitude and the "low" occurs regularly at about $5: 30 \mathrm{~g} . \mathrm{m}$. It is a mere coincidence that the cyclonic low happened to arrive about the same time. 
In figure 5 is shown the change in transmission of the filter, $B a-1$, with increase in the amount of ozone during the day. For comparative purposes the observed transmissions are reduced to the values that would have been observed through an air mass, $m=1.55$, as described in the second preceding paragraph.

In this illustration the barometer readings, " 29.18 in.," etc., are the uncorrected values read from the barograph record. For comparative purposes the barograph record of September 24 is set to the same scale (29.18 in.) to show the somewhat larger increase in pressure that usually occurs during midday. The corrected pressures $(29.85$ and 30.0 in., respectively) for these dates may be read from figure 4. A significant part of this illustration is the observation that the change in barometric pressure preceded by some 5 to 6 hours the advection (or formation) of an appreciable amount of ozone above

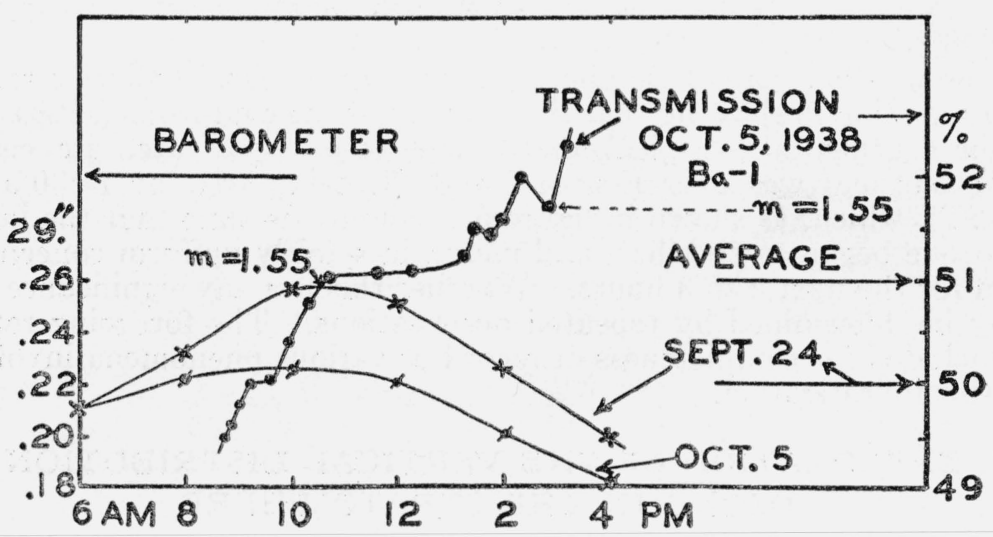

FIGURE 5.-Change in transmission of ultraviolet solar radiation through the filler, $B a-1$, caused by a change in atmospheric ozone, on October $5,1938$.

the average that obtained during the preceding days of relatively high atmospheric pressure.

Another significant point in this illustration is the irregularity in the increase in the transmission of ultraviolet through the filter, showing that this influx (or formation) of ozone is irregular, turbulent; a phenomenon that should, no doubt, be expected. Whether the small increase in barometric pressure had a stabilizing effect in keeping the filter transmission uniform at the noon hour (see fig. 5) is an interesting question.

In conclusion, it may be noted that the observed change in filter transmission represents an increase of 8 to 10 percent in the amount of atmospheric ozone during the barometric low pressure of October $5,1938$.

Supplementing the above cited references [10 to 14], showing variations in the amount and distribution of ozone in the upper atmosphere, the foregoing measurements on the variation in transparency of the atmosphere with meteorological conditions supply additional evidence showing that such variations from day to day are to be expected. 


\section{AIR-MASS ANALYSIS OF OCTOBER 5, 1938}

Since writing this paper, Edgar W. Woolard, Chief of the Division of Meteorological Research (U. S. Weather Bureau), has sent us an analysis of the weather maps for October 3 to 7 , inclusive, prepared by the personnel of his Air Mass Section. His report dated January 19,1939 , is as follows:

Frontogenesis appears in Utah and Arizona on the 7:30 a. m., EST, map of October 5 due to cooler air flowing in from the northwest as indicated by the San Diego meteorograph ascent.

As this cool air passed over the warm surface of Arizona, Southern Utah, and New Mexico, it was heated rapidly at low levels wiping out the discontinuity between air masses over the great basin. However, this cooler air is still observed aloft on October 6, causing the steepened lapse rates at Cheyenne, Wyo.; Salt Lake City, Utah; and El Paso, Tex.

Another influx of colder air from the northwest (note temperature drop at San Diego, Calif.) created a new cold front on the morning of October 7 through Southern Utah and Arizona.

The weather map of October 5 accompanying Dr. Woolard's report is interesting in showing that the position of the cold front $(c P+m T k$; polar continental + tropical maritime-steep lapse rate, air cooler than surface) was over Flagstaff and Phoenix, Ariz., at 11:30 a. m. (MST), which, as shown in figure 5, is about the time that the influx of ozone began to stabilize, and maintain a fairly uniform concentration for the next 2 to 3 hours. Whether this has any significance can only be determined by repeated observations. The foregoing report is included for completeness of record of various phenomena involved in this investigation.

\section{EXPLORATION OF THE VERTICAL DISTRIBUTION OF OZONE IN THE STRATOSPHERE}

Under the present heading is given a description of the results obtained during June 1938 in measuring ultraviolet solar intensities and thereby in determining the vertical distribution of atmospheric ozone at various elevations above the earth's surface. The apparatus and methods used are essentially the same as previously employed $[5,6]$ but embody improvements that naturally develop as the result of the discovery of weak points that are found in the course of development of any new project. The chief improvements were in the radio-transmitting system [7], whereby it was possible to measure ultraviolet intensities to the height ( 25 to $27 \mathrm{~km}$ ) attained by the transporting balloons; in contrast with last year's ascensions, when, as already stated, the ultraviolet-intensity measurements ceased at $19 \mathrm{~km}(64,000 \mathrm{ft}$.)

Briefly summarized, an ultraviolet-intensity meter, consisting of a photo-electric cell and filter radiometer, connected with an audiofrequency generator and radio transmitter, is transported aloft by means of unmanned balloons. The height attained by the balloons is indicated by a radio barograph. The radio signals giving the altitude of the apparatus and the ultraviolet intensities are received and recorded graphically at a ground station. In this paper only the improvements in apparatus and methods, with brief references to the previous paper, will be given. 


\section{DESCRIPTION OF THE RADIO-OPERATED ULTRAVIOLET- INTENSITY METER}

An earlier model of the ultraviolet-intensity meter, consisting of a spherical-shaped photoelectric cell and filters which controlled a radiowave transmitting device, was described in previous papers [5, 6]. Unfortunately, the interior coating, which constitutes the photosensitive surface of the cell, was not so uniform in response as in the cells used a year ago. Hence, to minimize this defect the window of the photoelectric cell was covered with two superposed fine-ground diffusing plates of Corex $A$ glass $(C x$, with a black paper window 17 $\mathrm{mm}$ in diameter; fig. 6) instead of one diffusing plate, as used a year ago. This produced a fairly uniform response curve for different. angles of incidence, somewhat similar to the response curve shown in. fig. 6 of the previous paper [6].

In figure 6 is shown a photograph of the assembled apparatus, housed in a balsa-wood box, open at the top and front to show the most important parts of the apparatus. The relaxation oscillator and radio transmitter occupy the rear half of this box.

The present ultraviolet filter apparatus differs from that used a year ago in that all four of the elliptical openings in the cardboard disk were covered; two of the openings being covered with glass filters ( $F$ in fig. 6), and the other two openings with thin perforated metal screens, $S$, the holes of which were drilled of a size to transmit approximately 30 and 50 (actually 27 and 48 ) percent, respectively, of the total incident solar radiation. These perforated metal screens (thickness $0.06 \mathrm{~mm}$ ) served two important purposes: (a) being nonselective in transmission, the ratio of the intensities (scale readings on the electronic frequency meter) observed through these screens served as a check on the measurements with the glass filters; and (b) all the scale readings on the frequency meter and recorder being reduced to about the same size (fig. 8), it was possible to use a larger amplification of the scale readings at the ground level, and yet keep the recorder arm from going off the scale at the highest elevations (highest ultraviolet intensities), which occurred on one of the ascents in 1937, when the amplification of the scale reading was too high.

From the numerous details described in the previous report [6] it is relevant to note that the electric motors used in rotating the filters over the window of the photoelectric cell were of the same type as used in 1937.

Before making the ascents, each photoelectric cell outfit was calibrated against a standard of ultraviolet radiation [22]. As will be noticed later in this paper, with the much greater stability in this year's radio-transmitting device, the ultraviolet intensities, measured on different flights, are in much better agreement than obtained last year.

\section{DESCRIPTION OF IMPROVEMENTS IN THE RADIO CIRCUIT OF THE PHOTOELECTRIC ULTRAVIOLET-INTENSITY METER}

In a previous paper [6] brief mention was made of improvements in the photoelectric ultraviolet-intensity meter which, combined with the radio-operated barometer, is transported in unmanned balloons. As there stated, in the new instrument a stable electric circuit is obtained by amplifying the photoelectric current before it reaches the 
relaxation oscillator. Furthermore, the sensitivity of the entire unit is automatically tested each time the barograph interrupts the ultraviolet signal to give an indication of the altitude.

The instrument shown diagrammatically in figure 7 and briefly described in detail elsewhere [7] virtually combines the balanced direct-current amplifier [1] (previously designed for precision work in the laboratory) with a relaxation oscillator and short-wave transmitter, similar to that developed by Diamond and his collaborators [3]. Wired in this manner, sufficient power and sensitivity are available for the relaxation oscillator to operate under normal circuit constants (voltages, resistances, capacitances) and, hence, in a condition of stable equilibrium.

For a given photoelectric cell the sensitivity of the instrument depends upon the circuit constants of both the relaxation oscillator and the direct-current amplifier. Referring to figure 7, in the relaxation oscillator, keeping the other constants of the circuit fixed, the sensitivity is inversely proportional to the capacitance of $C_{1}$. The value of $R_{1}$ determines the base frequency of the oscillator with no light on the photoelectric cell.

In the balanced amplifier, with the plate voltages and resistances adjusted for proper operation, the sensitivity is increased or decreased by a change in $R_{2}$.

In operation, as a small motor rotates the disk, $D$ (fig. 7; see also fig. 6) carrying various filters over the photoelectric cell, the directcurrent amplifier becomes unbalanced in a degree proportional to the intensity of the light incident on the cell. This unbalance in the plate circuit of the amplifier (also a part of the grid circuit of the relaxation oscillator 1A6) causes an increase in the charging rate of the condenser, $C_{1}$, and, hence, the audio frequency of oscillation. Tests of the several instruments built and used in the 1938 flights gave frequency changes which were linear with variations in light intensity to within about 1 percent throughout the range of 50 to $200 \mathrm{c} / \mathrm{s}$.

The potentiometer arrangement, $K$, (fig. 7) consisting of two type- $Z$ Penlite cells, shunted by approximately 120,000 ohms, is connected with the barograph, $B$, which impresses fixed potentials on the grid of tube $T-1$ each time the contact arm reaches one of the segments of the pressure switch (see also $P S$ in fig. 6). This in turn causes an increase in audio-frequency oscillation indicative of the absolute sensitivity of the complete instrument (see $B, C$, or $D$ in fig. 8). In practice, the contacts, $b$ and $f$, (see fig. 7) are used as reference points of altitude only while the more numerous contacts, c, are used for both sensitivity calibration and altitude determination.

The aim has been to make the various units in this instrument small and light in weight and yet retain materials of sufficiently good quality to insure precision operation. Most of the resistor units are of the standard 0.5-watt type. The batteries are of minimum size sufficient to give about 3 to 4 hours of dependable operation. To give more reliable and stable operation of the direct-current amplifier, S. S. White or wire-wound resistors are used in the grid and plate circuits of this part of the instrument. This precaution is very important since a small change in these resistances may shift the audio-frequency base level ( $G$ in fig. 8) off the scale in either the positive or negative direction. A slight drift (usually downward) generally occurs during a flight. This is not a serious matter, however, so long as the drift is 


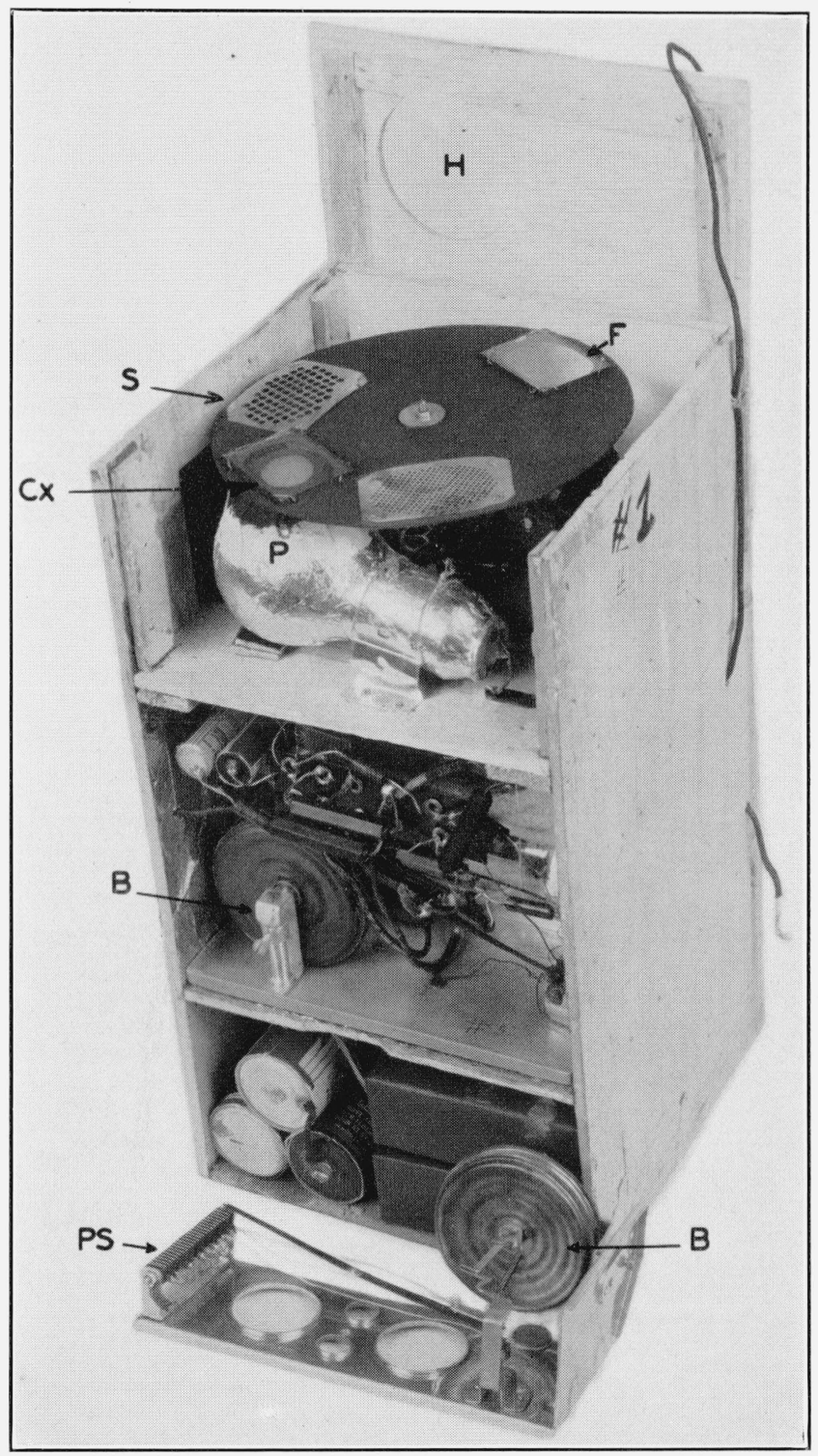

FIGURE 6.-Assembled stratosphere ultraviolet-intensity meter, housed in balsawood box, open at the top and front, showing the photoelectric cell, $P$, covered with a diffusing window Cx; the two glass filters, $F$; the two perforated metal screens, $S$; the radio-barograph, $B$, and pressure switching device, $P S$; the cover with hole, $H$, that exposes the photoelectric cell to the sun; and part of the radio accessories. 


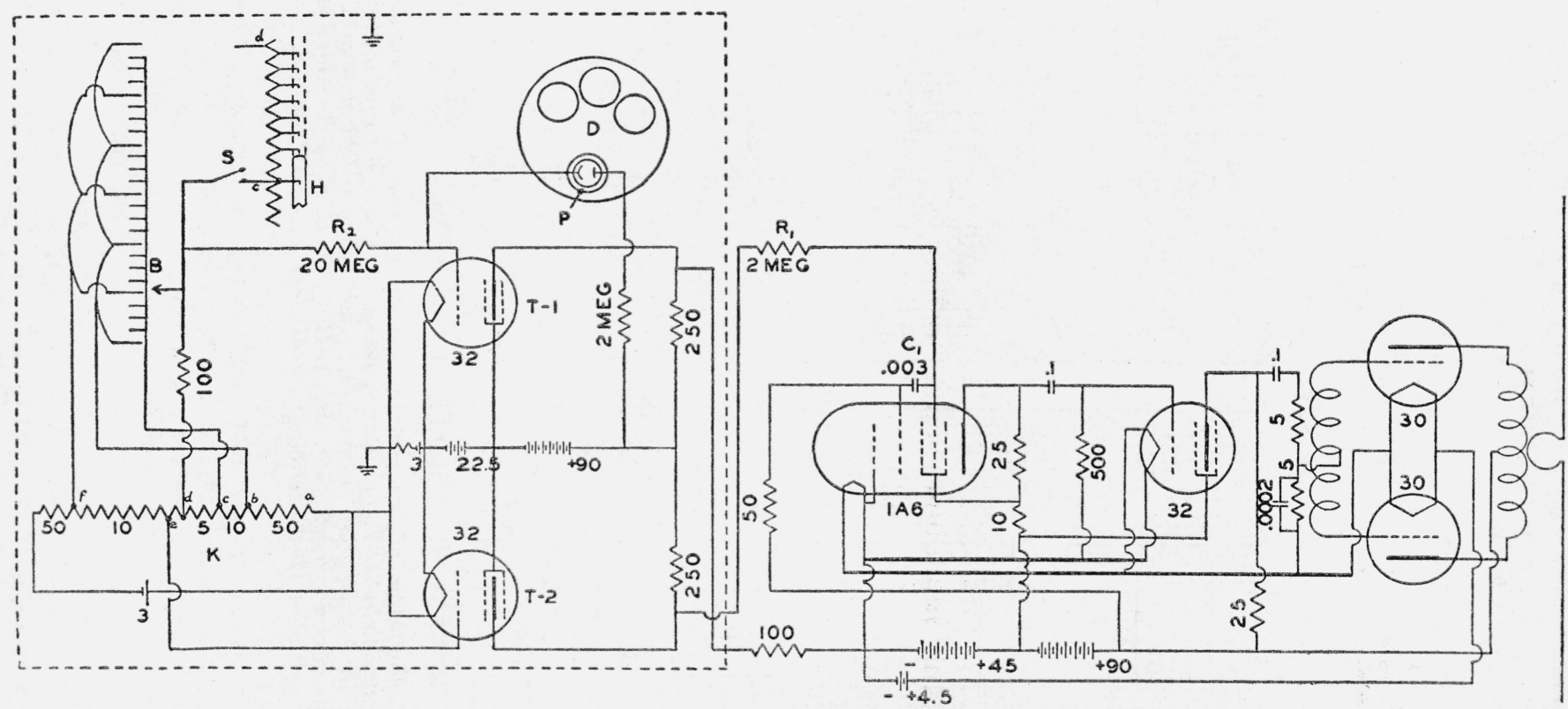

FIGURE 7.-Electric circuit of the photoelectrically controlled, $P$, audio-frequency generator, the amplifier circuit, and the radio-barograph circuit, $B$. 
not sufficient to reach the nonlinear portion of the scale (toward the lower frequencies) because the absolute sensitivity of the complete instrument (amplifier and relaxation oscillator) is checked each time a barograph contact is made.

\section{DESCRIPTION OF A BALLOON-FLIGHT RECORD}

In a previous paper $[5,6]$ a description was given of the groundstation receiving and graphically recording apparatus, consisting of a
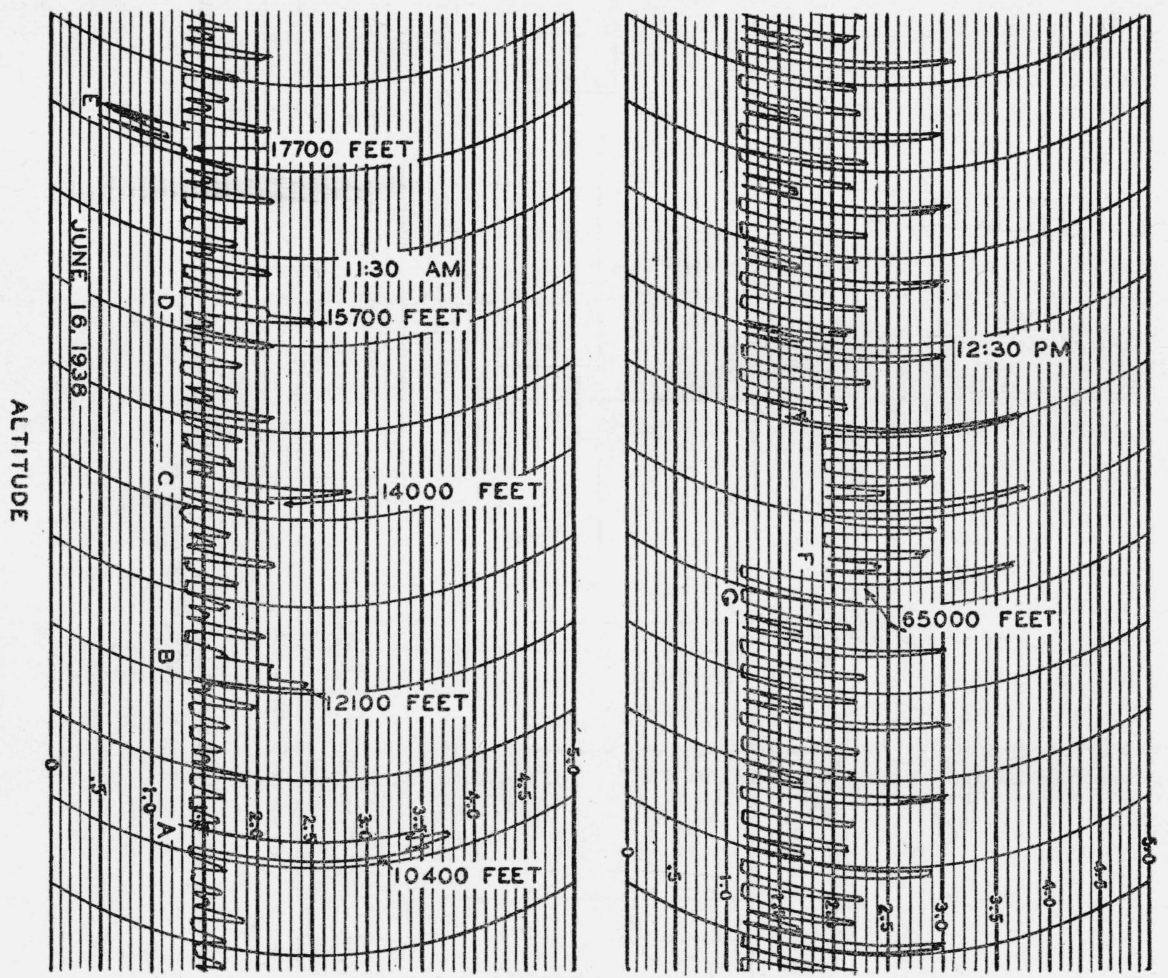

FIGURE 8.-Reproduction of two parts of a graphic record of the ascension of a stratosphere ultraviolet-intensity meter, showing the change in frequency (ordinates) with change in intensity of ultraviolet radiation transmitted through the glass filters; also the audio-frequency signals, $A, B, C, D, E, F$, of the radio-barograph showing the method of identification of the different altitudes attained.

super-regenerative receiving set, an electronic-frequency meter, an amplifier and electrical filter, and a recorder. To save time in the subsequent calculations, the values of the audio frequencies, emitted from aloft by the radio transmitter, were read directly on the dial of the electronic-frequency meter and written on the corresponding part of the graphic record shown in figure 8 .

Referring to figure 6 , it may be noted that, as the disk rotates, the large opaque spaces between the filter, $F$, and the two perforated metal screens, $S$, act as a shutter to exclude solar radiation from the photo- 
electric cell; and the lowest audio frequencies recorded (between the lower horizontal lines marked 1.0 and 1.5, fig. 8) are reference frequencies, analogous to a graphic record of the scale reading of a galvanometer.

In one complete rotation of the disk there are recorded four deflections of the recorder arm, representing four ultraviolet intensities; two through the glass filters, $F$, and two through the perforated metal screens, $S$, shown in figure 6 .

As noted in the previous paper $[5,6]$, with change in elevation, the arm of the radio-operated barometric-pressure apparatus crosses the metal contacts on the pressure switching element ( $P S$ in fig. 6) and an entirely different audio-frequency note is emitted, as indicated at the points $A, B, C$, etc., figure 8 . As already noted, the direction and the magnitude of the audio-frequency indication on the recorder serve to identify the altitude attained in the flight [28].

\section{(a) NOTES ON THE SIX FLIGHTS}

The weight of the complete apparatus including the rubber shock cord was close to $5 \mathrm{lb}(2.3 \mathrm{~kg})$. In all the flights latex balloons model 750 (the average weight in grams), made by the Dewey \& Almy Chemical Co., were used.

The apparatus was transported by three, four, or five balloons which were inflated with hydrogen to exert a total pull of about $10 \mathrm{lb}$, as determined with a small spring balance. When three balloons were used (each lifting $3 \mathrm{lb}$ ) the rubber was already under strong tension before ascension. When five balloons were used (each one inflated to lift about $2 \mathrm{lb}$; total pull, in quiet air, $11 \mathrm{lb}$ ) the rubber bags were not fully distended. Nevertheless, in each flight one or more of the balloons burst before reaching an elevation of 90,000 ft, showing that the heat and photochemical action of the (ultraviolet) solar rays, and presumably atmospheric ozone (and not the degree of distension of the rubber) were the cause of the failure of the balloons.

As regards the rate of ascent, it is relevant to record that this appears to depend on the total lifting force exerted, with little or no dependence upon the number of (i. e., interference by the) balloons. For example, in flights 1 and 2 , using three and four balloons, respectively, and a lifting force to 9 to $10 \mathrm{lb}$, the rates of ascent were, respectively, 950 and $940 \mathrm{fpm}$. In flights 4 and 5, each using four balloons, and a total lifting force of 10 and $11 \mathrm{lb}$, respectively, the rate of ascent was $1,000 \mathrm{fpm}$. In flight 6 , using five balloons and a total pull of $11 \mathrm{lb}$, the rate of ascent was $1,020 \mathrm{fpm}$. In this connection, it is of interest to note that in all of these ascents, when the balloons (tethered at different heights from a common meeting point $[5,6]$ ) were released they moved outward, as the result of air streaming, and remained in that position in their flight. All the ascents were made at Beltsville, Md. Out of six flights there were four recoveries of apparatus, as compared with five recoveries out of six flights made in 1937.

Flight 1.-Unit No. 5. Transported aloft by means of three balloons. Ascent started at 11:12 a. m., EST, on June 16, 1938. Balloons drifted NNE, through thick clouds-no sun. Descent started at 1:05 p. m., last signal at 2:10 p. m. Apparatus was recovered at about $3: 30$ p. m., at Cambridge, Md., about 50 miles 
southeast of the starting point. Finder reported that two balloons had burst. Maximum height attained was $82,700 \mathrm{ft}$.

Flight 2.-Unit No. 6. Transported by four balloons. Quiet ascent, drifting ESE. Sky covered with thin fracto-cirrus; a little sunlight through the clouds at the start. Ascent started at 10:29 a. m. on June 18. Descent started at 12:05 p. m.; last signal at 12:40 p. m.; no recovery of apparatus. Maximum height attained was $88,200 \mathrm{ft}(26.5 \mathrm{~km})$.

Flight 3.-Unit No. 4. Transported by four balloons. Sky lightly overcast at start; thick overcast a short while later. Quiet ascent SSW. Ascent started at 10:53 a. m., June 20. Apparatus visible to W. at 11:03 a. m. Noise after 11:18 a. m., altitude $26,000 \mathrm{ft}$. Radio silent after 11:27 a. m. No recovery.

Flight 4.-Unit No. 2. At the start there was sunshine through thick hazy sky; later fracto-cumulus clouds. Quiet, four-balloon ascent, drifting SSE. Ascent started at 10:47 a. m., June 23; good record to 50,000 ft. Radio off at 11:35 a. m., balloons still rising. Apparatus recovered at 3 p. m., two balloons still inflated, at Union Mills, Md., about 43 miles north of starting point.

Flight 5.-Unit No. 1. Sky turbid. Quiet, four-balloon ascent, drifting N, then NNE. Ascent started at 10:42 a. m., June 25; good record to top-close to $88,000 \mathrm{ft}$. Descent started at 12:30 p. m.; signals received until 2:05 p. m. Instruments recovered at 2:30 p. m. by a forest-fire lookout (stationed about 7 miles northeast of Manassas, Va.) who witnessed the two-balloon descent and recovered the instruments from the top of a tall tree. Maximum altitude attained was $87,300 \mathrm{ft}$.

Flight 6.-Unit No. 2. This was the second flight of this set of instruments, this time with five balloons. The ascent started at 10:51 a. m., June 30; and the descent, which began at 12:20 p. m., was followed till 2:05 p. m., when the signals became weak, although subsequently the sky was reported to have been "very clear" at that hour. The apparatus, with two balloons still inflated, landed at $3: 30 \mathrm{p}$. m. in an orchard near Adelina, Md., about 40 miles southeast of the starting point. Maximum altitude attained was $86,000 \mathrm{ft}$.

In all these fights it is interesting to note that the place of landing of the apparatus was at relatively short distances from the starting point and in a region that usually was situated in an entirely different direction from that noted when the ascent was begun. In view of the interest in these flights, relative to radio fadeouts, the Radio Section of the National Bureau of Standards reported that no fadeouts occurred in the radio signals; except on June 30 when there was a fadeout at 10:04 a. m., lasting until 10:30 a. m. On this same day, between 12:44 p. m. and 12:58 p. m., a slight fadeout was noted at the Toronto, Canada, receiving station.

Aside from the decrease in intensity of our ultraviolet-intensity radio signals at 2 p. m., which was ascribed to clouds (although later inquiry elicited the information that the sky had been "very clear") there is nothing in our ultraviolet-intensity measurements that indicates a connection between the radio fadeout and the ozone distribution in the atmosphere.

\section{EVALUATION OF THE ULTRAVIOLET-INTENSITY MEASUREMENTS}

The evaluation of solar ultraviolet intensities in the stratosphere involves no assumptions. The calculations require a knowledge of (a) the spectral-response curves of the photoelectric cells (shown in fig. 3 of ref. [6]); (b) the spectral ultraviolet transmissions of the filters (practically the same as $L S$ and $B a-1$ in fig. 3, ref. [6]), as employed in calculating data secured with our standard photoelectric-intensity meter at a ground station [21]; and (c) the spectral-absorption coefficient of ozone. Numerous determinations of the spectral-absorption 
coefficients of ozone in the atmosphere (required in the hereindescribed measurements) are in close agreement with similar measurements on ozone prepared in the laboratory [23].

Another important factor that enters into our calculations is the shape of the solar spectral-energy curve, of wave lengths shorter than

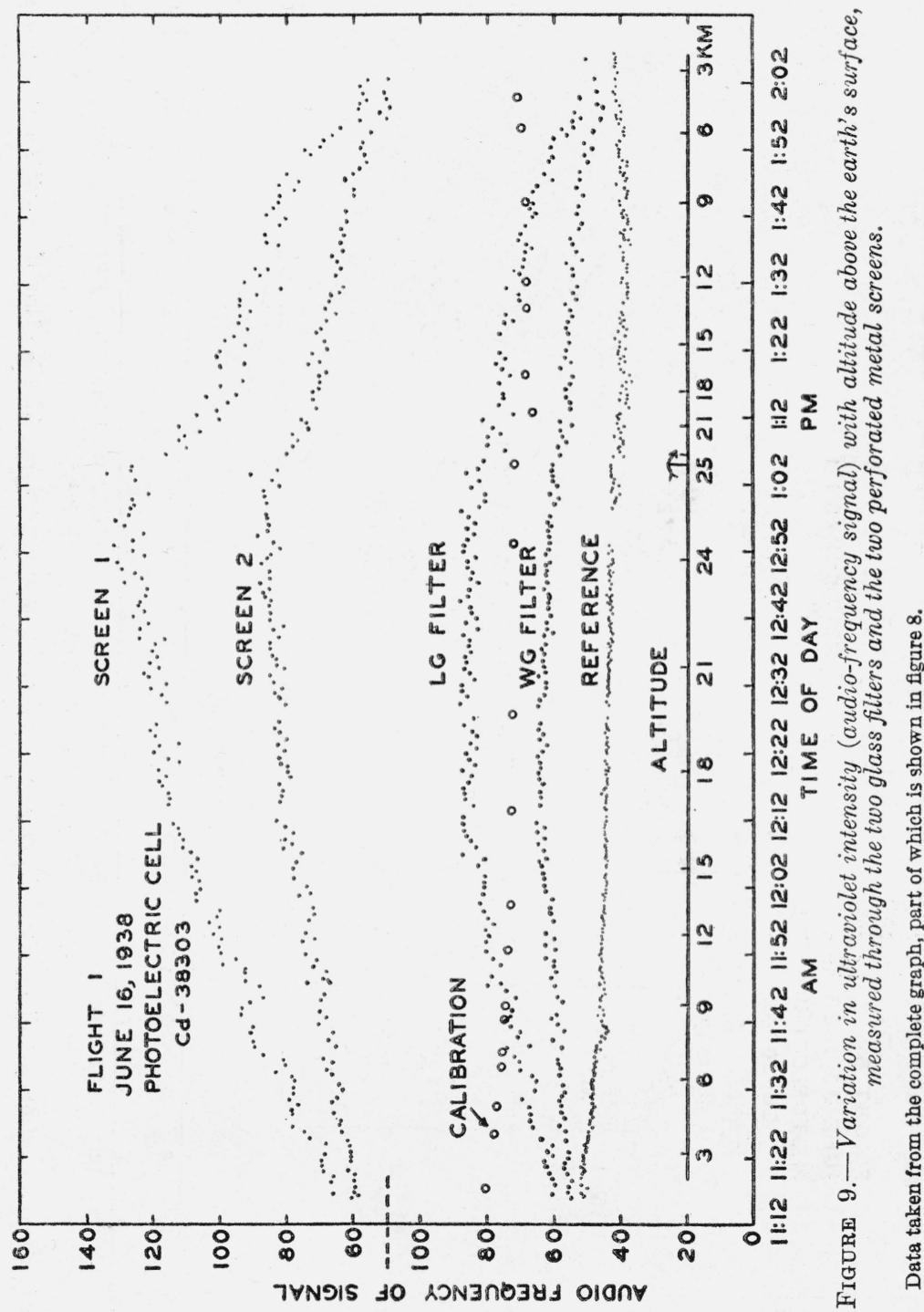

about $3200 \mathrm{~A}$, outside the earth's atmosphere. As shown in a previous paper [4], experimental data indicate that a calculation of the solar spectral-energy curve, using a black-body temperature of $6,000^{\circ} \mathrm{K}$, is inadmissible. Our curve of the solar spectral-energy distribution outside the earth's atmosphere [4] obtained with filters at sea level is in qualitative agreement with Pettit's spectral-energy measurements 
[24] obtained at an elevation of about $2,300 \mathrm{ft}(760 \mathrm{~m})$. We have, therefore, used Pettit's extra-terrestrial solar spectral-energy distribution in calculating the distribution of ozone in the stratosphere.

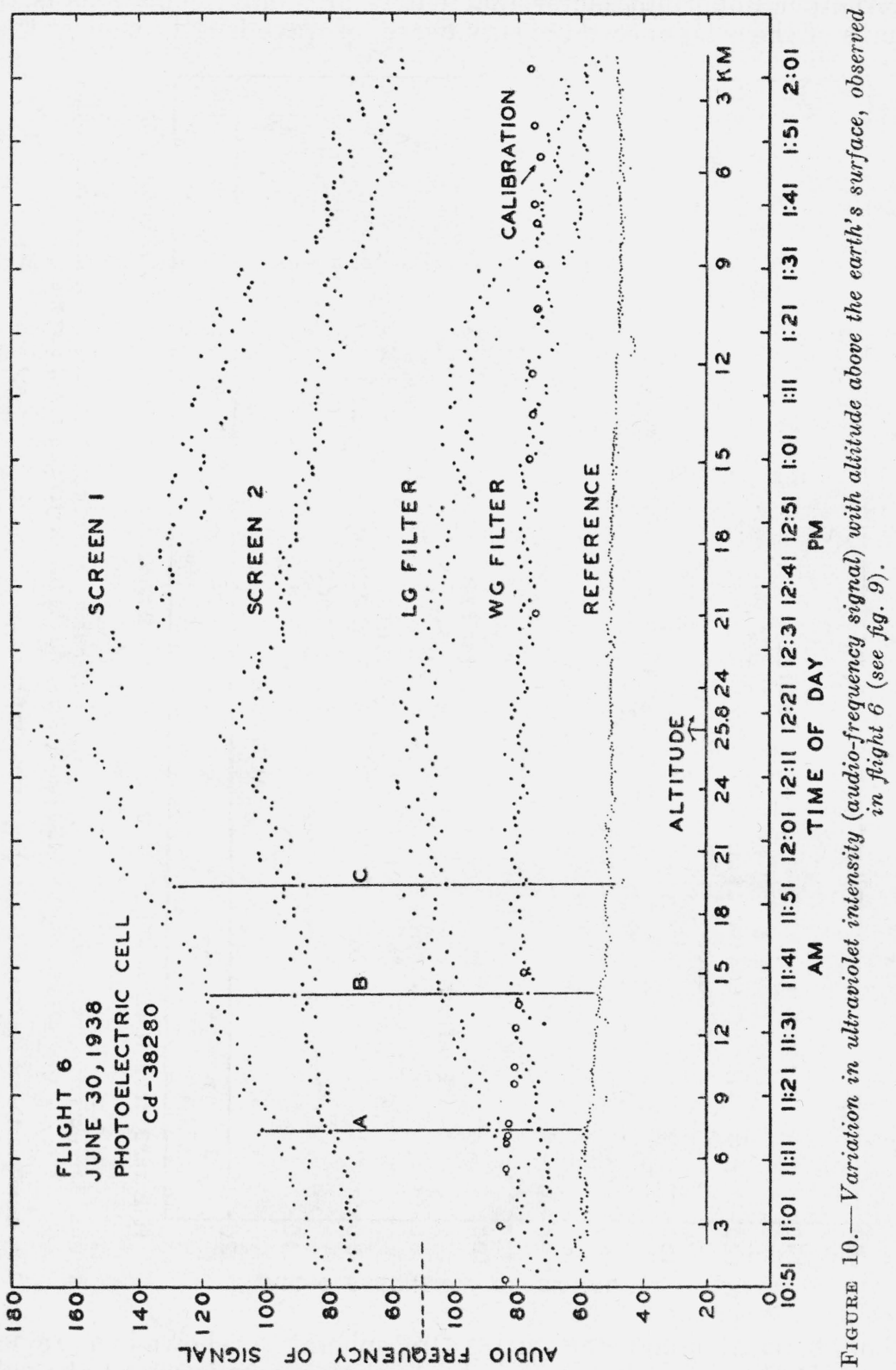

In figures 9 and 10 the series of points represent the audio-frequency signals (the ultraviolet intensities) observed during the flights of June 16 and 30,1938, respectively. These points are the maxima of the graphic record of the audio frequencies emitted by the photo- 
electrically controlled radio transmitter, during ascent and descent, parts of which record are shown in figure 8.

The designations $L G$ and $W G$ (figs. 9 and 10) represent the trade names of the glass filters used. The vertical lines $A, B$, and $C$ in figure 10 show the frequencies recorded in sequence of a single rotation of the disk. Some of the irregularities are caused by lack of uniformity in sensitivity of different parts of the photoelectric cell, which becomes apparent as the apparatus vibrates as a pendulum and rotates around the suspending cord. Another irregularity, which is eliminated in the calculations, is caused by a temporary drop in the reference frequency as depicted in line $C$, of figure 10, showing the importance of having a record of this part of the radio broadcast as well as the ultraviolet intensities through the filters and screens. For a further discussion of this question, reference is made to the preceding paper [6].

The data depicted in figures 9 and 10, and similar charts for the other flights were reduced by two methods: (a) By drawing a smooth curve through the observed points, and (b) by taking the arithmetical averages over intervals of 5 minutes (approximately $5,000-\mathrm{ft}$. changes in altitude). In spite of the apparently great irregularities in the observations, partly accounted for in the variation in the reference frequencies (see figs. 9 and 10) the calculated percentage transmissions of the glass filters ( $W G$ and $L G$ ) depicted in figure 11 do not depart from the smooth curves by a greater amount than is to be expected taking into consideration the various disturbing factors that enter into an ascent, and especially in the descent of the apparatus. In fact, the observations of flight 1, depicted in figure 11, compare favorably with measurements made in the laboratory, and demonstrate very clearly what may be expected when a better grade of photoelectric cell can be produced-the $C d$-cell used in flight 1 was the best of the lot used in this year's flights.

In figure 11 the percentage transmission of the filter, $W G$ (and $L G$ ) is the height of the ordinate of a point on the line $A$, in figure 10 above the reference frequency, divided by the height of the ordinate $I_{0}$ similarly deduced from the frequency scale for either screen 1 or screen 2. In figure 11 the transmission of each filter $(W G$ and $L G$ ) at a given elevation is the average of two calculations, using the readings of the two screens, 1 and 2.

Although all the steel plates had been assembled in two piles and each hole drilled through all, the transmissions of the finished screens differed from the average by about 1 percent, which was about 27 and 48 percent for screen 2 and screen 1, respectively. In the calculations for each flight, the actual transmission values of the screens (e. g., in flight $6 ; t r=26.4$ and 48.4 , respectively) were used in deducing the transmissions.

Since the photoelectric cell is selective in response, in the evaluation of ultraviolet data it is necessary to incorporate two important factors, designated $P$ and $G[6]$.

The factor $P$ depends upon the kind (the spectral response) of photoelectric cell and the constants of the relaxation oscillator. In practice it is equivalent to a standardization of the scale reading of the frequency meter in terms of radiation in microwatts per square centimeter, by exposure of each stratosphere ultraviolet solar-intensity meter to a standard of ultraviolet radiation [22]. 
The factor $G$ is used in evaluating the ultraviolet in solar radiation of wavelengths shorter than $3132 \mathrm{~A}$, relative to the total range of wavelengths intercepted by the photoelectric cell, and, hence, must be determined for each cell [21].

The observations must be corrected for solar height (angle of incidence on the photoelectric cell). The data in solar ultraviolet in-

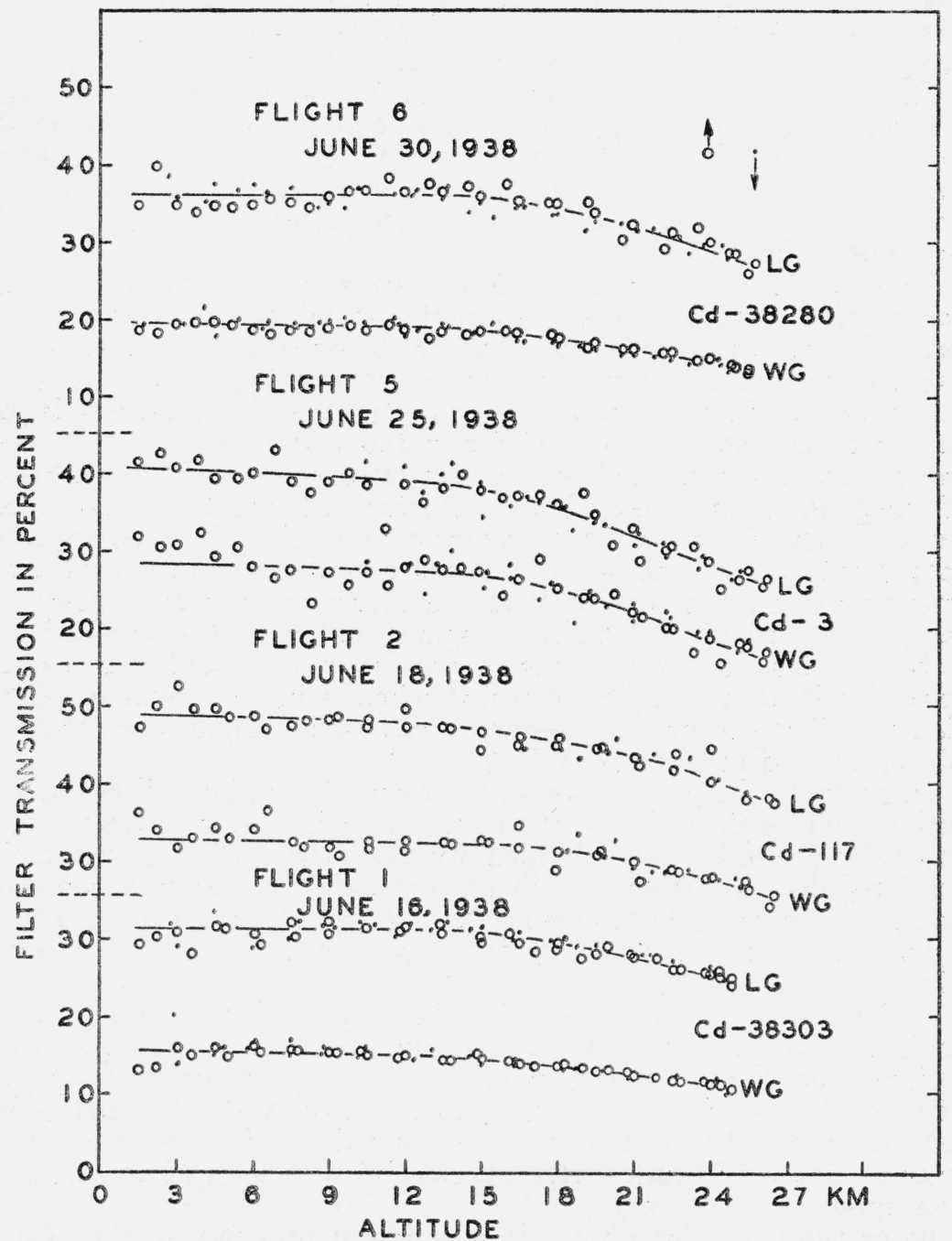

FiguRe 11.-Percentage transmission of the glass filters used in the various stratosphere flights.

The data were calculated by two methods as described in the text, based upon direct measurements, some of which are depicted in figures 9 and 10.

tensities are therefore reduced to an air mass, $m=1.04$. This correction is small, because only at the beginning of the flights was the solar height lower than the equivalent of $m=1.06$. For a more 
complete discussion of the various operations in reducing the data, the reader is referred to the preceding paper [6].

(a) VARIATION IN INTENSITY OF ULTRAVIOLET SOLAR RADIATION WITH ALTITUDE ABOVE THE EARTH'S SURFACE

Owing to clouds and possible disturbances from air currents in the lower atmosphere no attempt is made to accurately coordinate the data for elevations below about $9 \mathrm{~km}$.

By means of the measurements obtained with screens 1 and 2 , as depicted in figure 10, corrected for transmission, total ultraviolet solar intensities are obtained. To these values must be applied a factor $G$ to obtain the proportional part of wave lengths shorter than $3132 \mathrm{~A}$. The factor $G$ was determined for every $5,000-\mathrm{ft}$. $(1.5 \mathrm{~km})$ elevation; requiring a spectral-energy curve representing the filter transmissions at that particular altitude [21].

In figure 12 is given the intensity of ultraviolet solar radiation of wave lengths shorter than $3132 \mathrm{~A}$, at various elevations above sea level, observed on the four flights that attained high elevations. Each point is the average of 5 readings for each screen, or a total of 10 readings.

It is to be noted that beginning at an elevation of about $15 \mathrm{~km}$ there is a change in the trend of the ultraviolet intensities, indicating the region (tropopause) where the apparatus is entering into the region of rapidly increasing concentration of ozone. Above this point there is a marked change in trend to higher intensities as the apparatus penetrates, more and more, through the ozone layer. The high values in the region of 3 to $9 \mathrm{~km}$ are partly owing to scattered ultraviolet radiation from the sky and clouds, which, as already noted on a preceding page, amounts to some 25 percent of the total, in the clearest sky, at an elevation of $2.2 \mathrm{~km}$ (Flagstafi, Ariz.). The low values at 3 to $6 \mathrm{~km}$ for flight 2 are owing to clouds, as described on a preceding page.

In figures 11 and 12 , the arrows above the symbols associated with the flights on different days indicate the direction of movement (ascent or descent) of the apparatus.

At the highest altitudes attained, $27 \mathrm{~km}$, the intensity of ultraviolet solar radiation of wave lengths shorter than $3132 \mathrm{~A}$ is about 900 $\mu \mathrm{w} / \mathrm{cm}^{2}$. But even at this elevation, as will be shown presently, some 35 percent of the ozone remained above the apparatus. Extrapolated to a point outside the ozone layer this would indicate an intensity of about $1,500 \mu \mathrm{w} / \mathrm{cm}^{2}$, or more than $2 \frac{1}{2}$ times the value previously deduced [21] by extrapolation of measurements made at the earth's surface. One reason for this discrepancy is the fact that in the earlier extrapolation (as in the present one) the calculations do not take account of (do not include) wave lengths shorter than $2900 \mathrm{~A}$ which are observed at high altitudes, but do not occur in the measurements at low elevations, which form the basis for the extrapolation.

\section{(b) CALCULATION OF THE AMOUNT OF OZONE TRAVERSED}

In order to obtain an estimate of the amount of ozone traversed at a given height above the earth's surface it is necessary to correct the observed filter transmissions (fig. 11) for molecular (Rayleigh) scattering [6]. Then by means of the spectral-absorption coefficients of ozone [23] the effect of change in ozone thickness upon the 
filter transmission is calculated in the manner outlined on p. 210-212 of the previous paper [6]; the only difference being in the use of an ultraviolet solar spectral-energy curve for each height, instead of the average spectral-energy curve given in column 2 of table 2 of the previous paper [6]. Based upon the above outlined method of calculating the amount of ozone traversed, with elevation of the radiometric apparatus, the curves depicted in figure 13 are obtained. It is to be noted that each point is the average calculated from the transmission measurements of two filters, instead of one filter used in calculating the observations of 1937 .

An inspection of the curves in figure 13 shows that at a height of $18 \mathrm{~km}(60,000 \mathrm{ft})$ the amount of ozone traversed ranged from 0.024

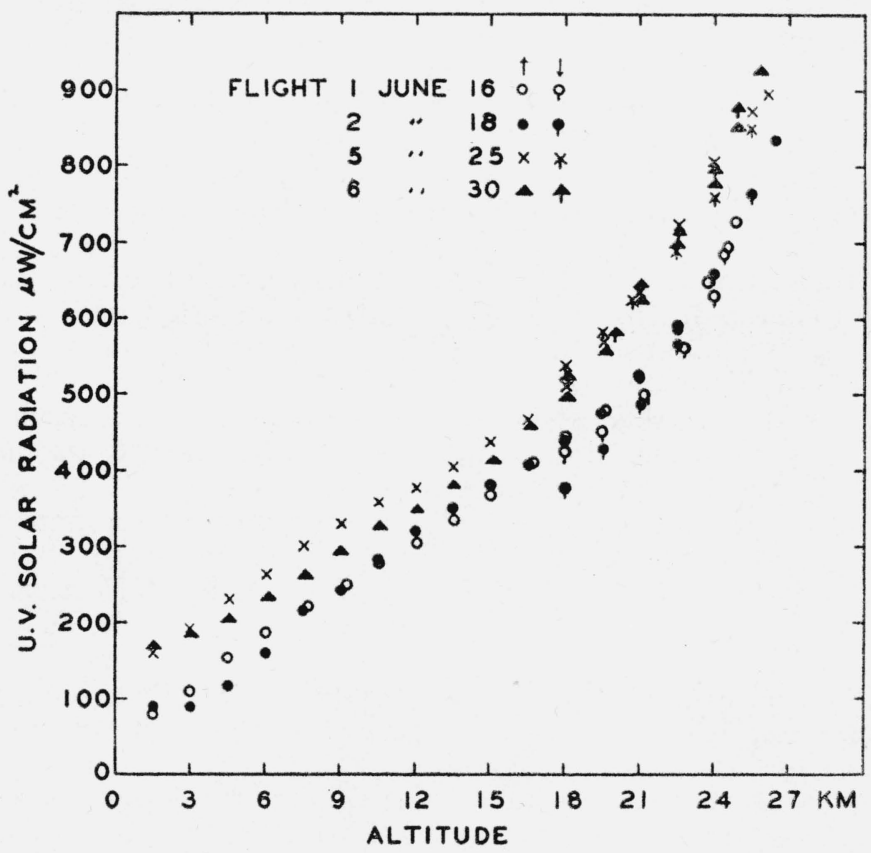

FIGURE 12.-Integrated ultraviolet solar and sky radiation intensities, of wave lengths shorter than 3132 A at various altitudes above the earth's surface.

to $0.035 \mathrm{~cm}$, or an average of $0.03 \mathrm{~cm}$ for the four flights that attained that altitude. Roughly, this amounts to 15 percent of the superposed ozone.

In the two flights of 1937 , the amounts of ozone penetrated at $18 \mathrm{~km}$ were 0.04 and $0.08 \mathrm{~cm}$, respectively, as deduced by one method of calculation and 0.025 and $0.05 \mathrm{~cm}$ by another method of calculation. Considering the crudeness of the instruments and methods employed in 1937, as compared with the much higher precision attained in the flights of 1938, the data are in good agreement in showing that below the $18-\mathrm{km}$ level there is a substantial amount of ozone relative to the total in the stratosphere.

In figure 13 the heavy black curve shows the average of all the flights of 1938. Flight 4 attained a height of only $15 \mathrm{~km}(50,000 \mathrm{ft})$, and in 
this range the amount of ozone traversed happens to coincide with the average of all the flights.

It is to be noted in figure 13 that the total amount of atmospheric ozone above the instrument, at sea level, on different dates ranges from about 0.19 to $0.25 \mathrm{~cm}$ (flights 6 and 1 ) with an average of 0.22 $\mathrm{cm}$. This is in good agreement with the average seasonal value for this latitude [12]. Such variations from day to day are to be expected, but in this series of measurements the precision attained is not sufficient to show a definite correlation of the amount of ozone with surface air pressure, such as described in section II of this paper. Calculations (and fig. 13) show that at an elevation of $27 \mathrm{~km}$ $(90,000 \mathrm{ft})$ the radiometric apparatus had traversed about 65 percent of the ozone layer.

In figure 13 the dotted curve NGS shows the part of the ozone layer traversed by the manned balloon (Explorer $I I)$ in November 1935 [2] also Regener's [25] curve of the flight with unmanned balloons in July 1934 . In both cases, the data were obtained photographically with a quartz spectograph. Regener's calculations are based upon a hypothetical solar spectral-energy curve at a black-body temperature of $6,000^{\circ} \mathrm{K}$ and an assumed ozone content of $0.28 \mathrm{~cm}$ (ntp), which is the average value for thatseason in the latitude where

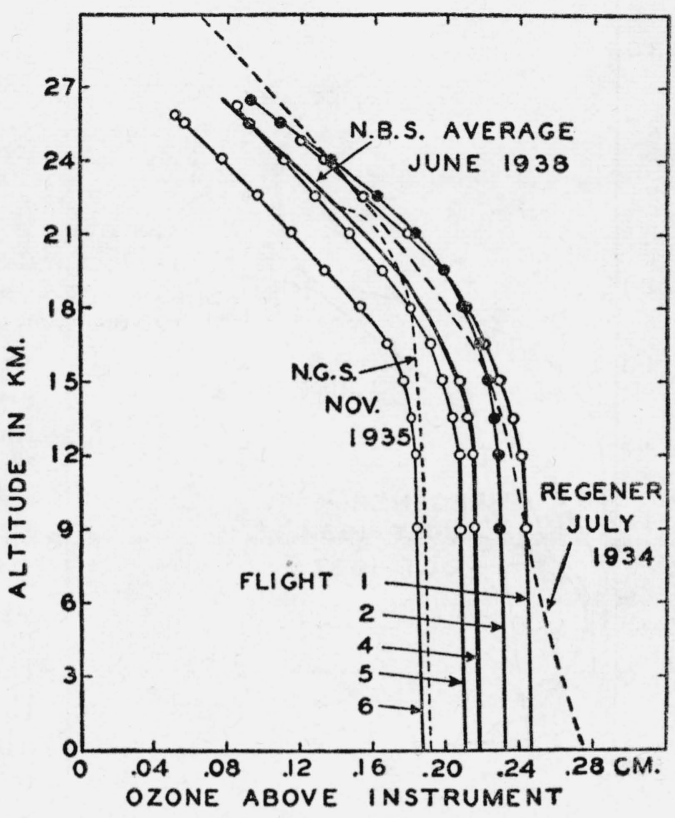

FIGURE 13.-Graphs showing the amount of ozone above the ultraviolet-intensity meter, at various heights above the earth's surface, observed in the fights of 1938.

Dotted curves show Regener's observations in 1934, and the National Geographic Society (NGS) measurements of November 1935 . the ascents were made.

In Regener's flights of June 26, July 7, and 31, 1934, respectively, heights of 20,30 , and $31 \mathrm{~km}$ were attained. At a height of $30 \mathrm{~km}$, exposures of 10 minutes registered wave lengths slightly longer than $2863 \mathrm{~A}$, and 70 percent of the ozone layer was below the apparatus. This is in substantial agreement with our measurements, taking into consideration the total amount of ozone present on a particular date and assuming no turbulence of the type recorded in section II of this paper.

In concluding this part of the presentation of data on the calculation of the amount of ozone in the stratosphere, it is relevant to compare the method of attack by different observers, particularly in the use of the solar spectral-energy curve, of short wave lengths, outside the earth's atmosphere. 
As noted elsewhere [4], for wave lengths shorter than about $3200 \mathrm{~A}$, calculations using a black-body temperature of $6,000^{\circ} \mathrm{K}$ are entirely in disagreement with the experimentally determined spectral-energy curve [29]. However, in the spectral region of 3200 to $3500 \mathrm{~A}$ the observed solar spectral-energy distribution [24] has approximately the same slope as that of a black body at $6,000^{\circ} \mathrm{K}$. Since the ultraviolet intensities in this part of the spectrum greatly exceed those in the region of 2900 to $3200 \mathrm{~A}$, rough calculations indicate that the use

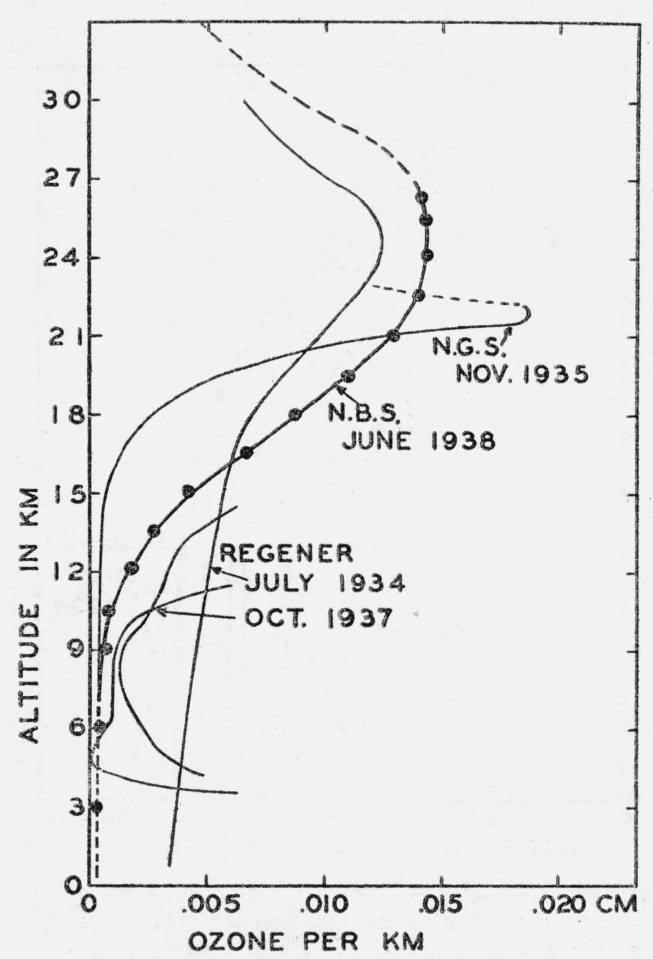

FIGURE 14.-Graphs showing the distribution of ozone at various elevations above the earth's surface. of a black-body energy curve at $6,000^{\circ} \mathrm{K}$ would have no marked effect upon the curves depicted in figure 13.

(c) VERTICAL DISTRIBUTION OF OZONE IN THE ATMOSPHERE

Differentiation of the curve (fig. 13) of average values of ozone at different heights above the ultraviolet meter gives the amount of ozone per kilometer $\left(\mathrm{O}_{3} / \mathrm{km}\right)$ at different elevations above the earth's surface. This is shown in the heary curve, NBS June 1938, in figure 14. The upper, dotted part of this curve shows the distribution required to account for the 35 percent of the ozone above the apparatus, at an elevation of $27 \mathrm{~km}$ above sea level.

Owing to clouds and presumably other effects upon the filter transmissions, at low elevations, no accuracy can be claimed for values below $6 \mathrm{~km}$; but, as shown in figures 11 and 13, beginning at about 9 to $12 \mathrm{~km}(30,000$ to 40,000 $\mathrm{ft}$ ) there is a definite change in the slope of the observed curves, indicating an appreciable penetration into the ozone layer.

As shown in the heavy curve in figure 14, and as noted in the flights of 1937, at a height of $12 \mathrm{~km}$ the change in ozone concentration is rapidly increasing - about $0.002 \mathrm{~cm} / \mathrm{km}$.

At an elevation of $15 \mathrm{~km}$ the concentration amounted to about 0.005 $\mathrm{cm} / \mathrm{km}$, and in the region of maximum concentration (at about $25 \mathrm{~km}$ ) the amount of ozone was about $0.015 \mathrm{~cm} / \mathrm{km}$.

The main portion of the ozone appears to be situated between 20 and $30 \mathrm{~km}$, with a region of maximum concentration between 23 and 27 $\mathrm{km}$, as previously observed by Götz at Arosa, Switzerland [18]. 
The sharply defined maximum concentration of ozone observed by O'Brien and his collaborators [2] (see fig. 14, curve NGS, November 1935 ) is entirely different from the results of other observers [18].

The earlier observations of Regener [25] (July 1934, in fig. 14) are in substantial agreement with the present explorations indicating a maximum concentration at a height of about $25 \mathrm{~km}$. His recent measurements [26] (October and December 1937, in fig. 14) are in general agreement with others between 5 and $10 \mathrm{~km}$ elevation.

In view of the effect of convection and turbulence during great changes in atmospheric pressure, as described in Section II of this paper, it is a question whether anything more than a general agreement in the form of the vertical distribution of ozone in the atmosphere is to be expected.

Acknowledgment is made to the National Academy of Sciences for a grant from the Joseph Henry Fund, which was used in defraying part of the expense of this investigation.

\section{REFERENCES AND NOTES}

[1] W. W. Coblentz and R. Stair, A portable ultraviolet intensity meter, consisting of a balanced amplifier, photoelectric cell, and microammeter, BS J. Research 12, 231 (1934) RP647.

[2] The National Geographic Society-U. S. Army Air Corps Stratosphere Flight of 1935, in the Balloon Explorer II, Nat. Geographic Soc. Contrib. Tech. Papers, Stratosphere Series No. 2, Washington (1936).

[3] H. Diamond, W. S. Hinman, Jr., and F. W. Dunmore, Bul. Am. Meteorolog. Soc. 18, 73 (1937); J. Aeronaut. Sci. 4, 241 (1937); J. Research NBS 20, 369 (1938) RP1082.

Development of a radio-meteorograph for measuring humidity, temperature, etc., at high elevations.

[4] W. W. Coblentz and R. Stair, Distribution of energy in the extreme ultraviolet of the solar spectrum, J. Research NBS 17, 1 (1936) RP899.

[5] W. W. Coblentz and R. Stair, A radiometric method of measuring ultraviolet solar-radiation intensities in the stratosphere, Bul. Am. Meteorolog. Soc. 18, 345 (1937); Radiologica 1, 12 (1937).

A brief description of the methods used and a preliminary report of the results obtained in the stratosphere flights of 1937.

[6] R. Stair and W. W. Coblentz, Radiometric measurements of ultraviolet solar intensities in the stratosphere, J. Research NBS 20, 185 (1938) RP1075.

Complete report of the results of the stratosphere flights of 1937.

[7] R. Stair, A precision radio instrument for transmitting measurements of ultraviolet intensities from unmanned balloons to a ground station, J. Research NBS 22, 295 (1939) RP1181.

[8] W. W. Coblentz and R. Stair, Factors affecting ultraviolet solar-radiation intensities, J. Research NBS 15, 123 (1935) RP816.

A study of the effect of fog, snow, sky, altitude, and geographic latitude upon ultraviolet solar radiation. See page 140 for a discussion of a low concentration of ozone.

[9] P. Harteck, Schwankungen des Ozongehaltes der Atmosphere, Naturwissenschaften 19, 858 (1931).

[10] G. M. B. Dobson and A. R. Meetham, Atmospheric ozone and meteorology, Quart. J. Roy. Meteorolog. Soc. (London) 60, 265 (1934).

[11] G. M. B. Dobson, D. N. Harrison, and J. Lawrence, Measurements of the amount of ozone in the earth's atmosphere and its relation to other geophysical conditions, Part II, Proc. Roy. Soc. London [A] 114, 521 (1927); part III, 12\%, 456 (1929).

A study of the distribution of ozone in cyclonic and anticyclonic areas.

[12] G. M. B. Dobson, Measurements of th amount of ozone in the earth's atmosphere and its relation to other geophysical conditions, part IV, Proc. Roy. Soc. London [A] 129, 411 (1930). Appendix I, by H. H. Kimball, p. 418; appendix II, by E. Kidson, p. 421.

Data and graphs are given of the amount of ozone in the earth's atmosphere as a function of the latitude and the season of the year. 
[13] R. Ladenburg, Light absorption and distribution of ozone, J. Opt. Soc. Am. 25, 259 (1935).

A review of the subject.

[14] F. W. P. Goetz, Seasonal variation in the amount of ozone at different latitudes. Gerlands Beitr. Geophys. 31, 119 (1931).

[15] K. O. Kiepenheuer, Über sonnenstrahlung zwischen 2,000 und $3,000 \mathrm{~A}, \mathrm{Z}$. Astrophys. 14, 348 (1937).

[16] A. R. Meetham, Correlaition of the amount of ozone with other characteristics of the atmosphere. Quart. J. Roy. Meteorolog. Soc. (London) 63, 289 (1937).

[17] A. R. Meetham and G. M. B. Dobson, The vertical distribution of atmospheric ozone in high latitudes, Proc. Roy. Soc. London [A] 148, 598 (1935).

[18] F. W. P. Goetz, Die vertikale verteilung des atmosphärischen ozons. Ergebn. Kosmischen Physik, III, 253-326, Leipzig, 1938.

An up-to-date summary of the researches on atmospheric ozone including 21 references to his own work, published since 1931. His survey of previous investigations on atmospheric ozone is published in the "Ergebnisse," I, 180-235 (Leipzig, 1931).

[19] F. W. P. Goetz and G. M. B. Dobson, Observations of the height of the ozone in the upper atmosphere, Proc. Roy. Soc. London [A] 120, 251 (1928).

[20] D. Barbier, D. Chalonge, et E. Vassy, Mesure de l'epaisseur réduite de l'ozone atmospherique pendant l'hiver polaire, Compt. rend. 201, 787 (1935).

[21] W. W. Coblentz and R. Stair, Evaluation of ultravio solar radiation of short wave lengths. J. Research NBS 16, 315 (1936) RP877.

[22] W. W. Coblentz and R. Stair. A standard source of ultraviolet radiation for calibrating photoelectric dosage-intensity meters, J. Research NBS 16, 83 (1936) RP858.

[23] C. Fabry and H. Buisson, Data on ozone absorption, Compt. rend. 192, 457 (1931).

$\mathrm{Ny}$ Tsi-Ze et Choong Shin-Piaw, Compt. rend. 195, 309 (1932); 196, 916 (1933).

F. W. Paul Goetz, Ergebn. Kosmischen Physik 3, 253 (1938).

[24] E. Pettit, Measurement of ultraviolet solar radiation. Astrophys. J. 75, 185 (1932); Pub. Astronom. Soc. Pacific 47, No. 280 (December 1935).

[25] E. Regener and V. H. Regener, Aufnahmen des ultravioletten sonnenspektrums in der stratosphere und vertikale ozonverteilung. Physik. Z. 35, 788 (1934).

[26] V. H. Regener, Neue messungen der vertikalen verteilung des ozons in der atmosphäre. Z. Physik 109, 642 (1938).

[27] Arthur Adel, V. M. Slipher, and E. F. Baker. The absorption of sunlight by the earth's atmosphere in the remote infrared region of the spectrum, Phys. Rev. 47, 580 (1935).

[28] Nat. Advisory Comm. for Aeronaut., Tech. Report 538 (1935). Altitudepressure table based upon U. S. standard atmosphere.

[29] D. H. Menzel, J. G. Baker, and L. Goldberg, Equivalent widths and temperature of the solar reversing layer. Astrophys. J. 8\%, 81 (1938).

They find that $4400^{\circ} \mathrm{K}$ best represents the mean effective excitation temperature of the reversing layer. The higher value $\left(5700\right.$ to $\left.6000^{\circ} \mathrm{K}\right)$ is a kinetic temperature. The two need not necessarily be the same.

[30] Preliminary studies of filter-transmission data, obtained at Washington, D. C., indicate that, instead of barometric pressure, more attention should be given to the movement of masses of polar air.

WAShington, January 15, 1939. 